\title{
H.G. Wells and South Africa
}

\author{
Shane Moran \\ OCID iD: https://orcid.org/0000-0002-4654-1705
}

\section{Abstract}

This essay links the idea of global apartheid and the enslavement of humanity to the preoccupation with South African evident in the texts of H.G. Wells (1866-1946). I show that the idea of human progress articulated by Wells drew on his interpretation of South African economics and politics in the aftermath of the Second Boer War. His treatment of South Africa in terms colonialism and participation in the debate about liberal imperialism and world government are of historical interest. The interpretation colonisation and race tyranny in terms of alien invasion is of immediate relevance to current debates concerning globalisation as late modern colonialisation. This essay aims to point out future areas of research for those concerned with colonialism (past and present) and resistance.

Keywords: global apartheid, science fiction, world government, great reset, development, recolonialisation, pandemic, alien invasion, technology.

We have been born and brought up in a social order that is now obviously a failure in quite primary respects. Our social order is bankrupt. It is not delivering the goods. It is defaulting and breaking up. War, pervading and increasing brutality, lack of any liberty, economic mismanagement, frightful insufficiency in the midst of possible superabundance - am I overstating the indictment? (Wells 1937: $164-165)$.

What H.G. Wells termed 'the chastening experience of the Boer War' (1914: 
23) informed his understanding of world government ${ }^{1}$. Wells saw South Africa as symptomatic of the inter-imperial competitive scramble for industrial and economic advantage - a cryptogram of the past and a possible exploitative future. The linkage between Wellsian intergalactic Darwinism, or cosmic sociology, and South Africa throws into relief the ongoing debate regarding golbalisation (see Bell 2018; and Wagar 1961). Today not only is national sovereignty in question, so too is the project of globalisation: 'More fundamentally, our basic narrative has lost its credibility and appeal ... We need a new narrative to shape the next stage of globalization' (Rodrik 2011: xiii) $)^{2}$.

As the rest of the world catches up with South African levels of inequality, the South Africanisation of the globe (see Gorz 1989: 156) ${ }^{3}$ suggests that the former polecat of the world community may represent the future rather than the past. Indeed for some race as a marker of global dominance and subjection is a useful resource ${ }^{4}$. The phrase 'global apartheid' 5 is used to mean minority rule in international decision-making, and implies a parallel between Bantustans and the poorer states in the underdeveloped world. Is the age of post-politics unfolding new forms of apartheid and colonisation? As Slavoj Žižek (2015) remarked: 'Maybe we'll just go on and end up in a new apartheid nightmare' ${ }^{6}$. Such foreboding points to the need to

${ }^{1}$ Wells's interest in South Africa predates the Second Boer War (see Wells 1894: 22). See also Wells (1896) on Olive Schreiner's The Story of an African Farm.

${ }^{2}$ See also Jacques Derrida (2005: 57); Eric Toussaint (1999); and Quinn Slobodian (2018: 87 - 88).

3 'Beyond the specifics of South Africa, the term apartheid can be applied to the global order, that is, the so-called New World Order, and not simply as an effective metaphor' (Harrison 2008: 24).

4 'Race making - the construction of race as a way to rationalize global inequalities - also creates a basis for global collective action' (Mullings 2008: 11).

${ }^{5}$ See Gernot Koehler (1995); Patrick Bond (2004); and Jaco Barnard-Naudé (2017:119).

${ }^{6}$ See also Alan Freeman \& Boris Kagarlitsky (2004: 29); and Fredric Jameson (2005: $384-392$ ). 
understand the colonial roots of apartheid, and Wells is an invaluable guide to this genealogy ${ }^{7}$.

In 1933 Wells saw the inevitable 'black revolt in South Africa' (1935: 156) as precursor to global conflict, and the privileged locus for the perpetuation of racist delusions and prejudices ${ }^{8}$. Benita Parry (2004: 150) has analysed Tonay-Bungay's 'parable and critique of investment capitalism's disintegrative effects on England's social structure', , and this insight can be taken further to demonstrate the central place of South Africa. South Africa allows us to move beyond the mutually reinforcing attempt to portray Wells as liberal fascist or new liberal ${ }^{10}$. Arguing in A Modern Utopia (1905) for the world-wide synthesis of all cultures and polities and races into one World State, South Africa's racial capitalism is identified with the need for labour. This is the central point driven home in Wells's interest in South Africa that is amply demonstrated in The New Machiavelli (1910), The Passionate Friends (1913) and The Research Magnificent (1915).

Wells's brother, Fred, served in South Africa during the Second Boer War (1899-1902) and subsequently opened Wells's Drapery Store in Johannesburg. Wells's daughter and her husband also visited South Africa, Anna

${ }^{7}$ See also Wells (1920: xiv); Arthur C. Clarke on South Africa (1990: 12); and Nicholas Visser's (1993) prescient discussion. For Olaf Stapledon's (1999a: 252) intergalactic narrator: 'Imagination withdrew and returned to Africa ... where Dutch and English profit by the Negro millions, those hosts were stirred by vague dreams of freedom. Peering beyond the whole bulge of Africa, beyond cloud-spread Table Mountain, I saw the Southern Ocean'. 8 'The spirit of the plantation broods over all these lands. The Negro in America differs only from his subjugated brother in South Africa or Kenya Colony in the fact that he also, like his white master, is an immigrant. The situation in Africa and America adjusts itself therefore towards parallel conditions, the chief variation being in the relative proportions of the two races and the details of the methods by which black labour is made to serve white ends' (Wells 1933: 57).

${ }^{9}$ See also Bernard Magubane (1996: x - xi) on 'Wells and the Boer War'.

10 See Jonah Goldberg (2009); Richard Toye (2008); and Mark Somos (2011). For Gabriel Hankins (2019: 70), Wells constructed 'a position beyond the liberal imperialism of his day'. See also Sarah Cole (2020); and Bernard Semmel (1960: 76 - 82). 
Jane lecturing in economic history at the University of the Witwatersrand. Criticising the bullying imperialism of Kipling, Wells compared the machinations that produced the Boer War with the mismanagement of Ireland, the 'two open sores of irreconcilable wrong' (1920: 424; and see $467)^{11}$. Wells's connection with South Africa is key to his understanding of imperialism and his ideas about world government. And this in turn sheds light on contemporary arguments about globalisation. I argue that Wells's speculative fictions are a means whereby 'one trains one's imagination to go visiting', (Arendt 1992: 43, and see Arendt 2007) and his influence has been felt in South Africa.

\section{Forced Landing}

Mathatha Tsedu's short story 'Forced Landing', published in the early 1980s, rewrites both Wells's The War of the Worlds (1898) and Joseph Conrad's Heart of Darkness (1899). It begins:

It was in the year 2561 that a cruising missile from Mars on its way to Saturnus was forced to make an emergency landing on Jupiter because of food shortages aboard. Contrary to popular belief that Martians are intelligent, on that specific journey - which was their first on that route - they had made a fatal mistake (Tsedu 1980: 69) ${ }^{12}$.

Tsedu's story of an attempted Martian invasion relays how in the recent past

${ }^{11}$ See also Wells (1904: 87) and Wells (1919). Commenting on the spirit of Imperialism in Britain and Ireland, Wells noted: 'If the continually irritated sore of the Majuba defeat permitted the country to be rushed into the needless, toilsome and costly conquest of the Boer republics in South Africa, the strain of that adventure produced a sufficient reaction towards decency and justice to reinstate the Liberal Party in power, and to undo the worst of that mischief by the creation of a South African confederation' (1920: 464). ${ }^{12}$ Other notable South African political futurology includes former mayor of Durban Archibald Lamont (1923) and Arthur Keppel-Jones (1947). More recent examples are Eben Venter (2008) and Nick Wood (2006). See Dierdre Byrne (2004/5): 522 - 525); and Roslyn Weaver (2010: 99 - 114) on indigenous Australian use of the apocalyptic to register colonialism. 
the population of Jupiter have read a book found on the moon that recounts the colonisation of a place called Azania by visitors who renamed the country Safrika. The Anazian people of Jupiter 'believed the book was a warning to them not to extend their hospitality to strangers of colour' $(71)^{13}$. Then visitors or 'aliens' (69) arrive from another planet: 'Dr Mudzimba vaccinated them against various diseases' (70). Shortly thereafter the visitors from Mars who were welcomed in good faith reveal themselves to be 'conspiring to colonise the whole country and subject it to the unjust philosophy of capitalism' (71). The Martians are promptly executed and colonisation thwarted. Divide and rule is strangled at birth.

The Juperterian Anazian people celebrate the rescue of their country 'from being clawed by the mercenaries of capitalism and cosmic neo-colonialism' (72). The visitors were after all on their way to Saturn ( $\hbar)$, named after the Roman god of agriculture and wealth. The colonial process of land annexation, labour exploitation and resource extraction was avoided, at least on Jupiter. The colonising Martians had miscalculated the resistance of those slated to be exploited - 'they had made a fatal mistake' (69) - for the Anazians were on their guard against strangers 'of colour' (71). The horror of colonial warfare is nipped in the bud by knowledge and decisive action rather than unwitting microscopic allies ${ }^{14}$. Anazian world government foiled alien

${ }^{13}$ Heart of Darkness: 'I believed it [Africa] in the same way one of you might imagine there are inhabitants on the planet Mars' (Conrad 1988: 29). However, according to another account, landing on Mars the Earthling finds traces of Africa: 'Los burned half his matches examining the curious mask. Shortly before his departure from the Earth, he had seen photographs of similar masks, discovered among ruins of giant cities on the Niger, in the part of Africa where signs of an extinct culture suggested a race mysteriously vanished' (Alexei Tolstoi 1950: 42). According to Tolstoi's 1923 text, Mars was colonised by terrestrial Atlantians who enslaved the indigenes and built the canals visible from Earth.

${ }^{14}$ The War of the Worlds: 'These germs of disease have taken toll of humanity since the beginning of things - taken toll of our prehumen ancestors since life began here. But by virtue of this natural selection of our kind we have developed resisting-power; to no germs do we succumb without a struggle .... But there are no bacteria on Mars, and directly these invaders arrived, directly they drank and fed, our microscopic allies began to work their 


\section{Shane Moran}

colonisation.

As with Wells's The War of the Worlds (1898), humanity (or the Jupiterians) survived to live another day ${ }^{15}$. What Tsedu adds to the modern mythos is technological parity between invaders and indigenes and the presence of collaborators - Bantustan leaders - willing to participate in the destruction of their own people. The normal colonialist perspective as expressed in The Time Machine - 'Conceive the tale of London which a negro, fresh from Central Africa, would take back to his tribe!' (Wells 1995: $41)^{16}$ - is reconceived as the tale of Africa and colonisation told by its potential victims ${ }^{17}$.

overthrow .... It was inevitable. By the toll of a million deaths man has bought his birthright of the earth, and it is his against all comers; it would still be his were the Martians ten times as mighty as they are. For neither do men live nor die in vain' (Wells 2012: 176 - 177). See also Robert Potter (1892). Ray Bradbury's '- And the moon be still as bright' (1948) has the Martians destroyed by disease brought by human colonists.

15 According to Wells the original idea for The War of the Worlds was suggested by his youngest brother Frank during a walk in the peaceful Surrey countryside. 'Suppose some beings from another planet were to drop out of the sky suddenly', said Frank, 'and began laying about them here!' Perhaps we had been talking of the discovery of Tasmania by the Europeans - a frightful disaster for the native Tasmanians! I forget. But that was the point of departure' (in I.F. Clarke 1992: 84). See Bernard Bergonzi (1961: 124). In the sequel to The War of the Worlds, Stephen Baxter's The Massacre of Mankind (2015), the Martians target Durban.

${ }^{16}$ See also Eric D. Smith on 'the very vibrant tradition of Bengali SF that precedes even the novels of H.G. Wells' (2012: 70).

17 'The original founders of the [Earth] City of a Hundred Golden Gates were African Negroes of the Zemze tribe. They deemed themselves to be the junior branch of a black race which in the dimmest antiquity populated the gigantic continent of Gwandan, now lying at the bottom of the Pacific Ocean. Its survivors had broken up into numerous tribes. Many of them had become savages. But the memory of their great past was treasured by the Negroes' (Tolstoi 1950: 69). Did Tolstoi's Aelita contribute to Stan Lee and Jack Kirby's hero Black Panther who made his comic book debut in 1966 and film appearance in Black Panther (2018)? 
In Tsedu's version any technological superiority on the part of the Martians is offset by the preparedness of the Anazians who have not forgotten the lessons of the past (their own past?) ${ }^{18}$.

Apartheid South Africa and the struggle against colonialism are given universal significance through the genre of science fiction, and apartness - but not race solidarity - is avoided. As Wells remarked, the weakness of his The War of the Worlds was overestimating the enemy: 'The only impossible thing in the story was to imagine that the Martians would be fools enough to try anything of the sort' (Wells 1937: 62) ${ }^{19}$. The anti-colonial rewriting takes this fully into account.

I like to imagine that the book found on the moon and read by the Anazians was H.G. Wells's The First Men in the Moon (1901). Did the Anazians read the account by Wells's businessman narrator of the resistance of the indigenous moon-creatures to their attempted colonisation? Perhaps the notes of the other visitor, the scientist Cavor, who was left stranded on the moon were found by the Anazians? Explaining that 'Our States and Empires are still the rawest sketches of what order will some day be', Cavor tells the Grand Lunar and his council 'the story of earthly War ... of invasions and massacres ... I went on to describe a Maxim gun in action and what I

18 Another source for Tsedu's tales might be Edgar Rice Burroughs's 1923 adventure: 'Its [Martian] commander in his heroic fight against the pull of the sun had managed to fall within the grip of Jupiter and was, when last heard from, far out in the great void between that planet and Mars' (Burroughs 1981: 32). The John Carter of Mars series (1912 - 1964) includes a visit to Jupiter, and on Mars the hero of pioneer stock and former Confederate soldier encounters warring groups battling over scarce resources on an environmentally hostile 'dying planet' (Burroughs 1917: n.p.).

19 In 1908 Alexander Bogdanov had the Martians weigh up the options regarding Earth and the problem with colonisation: 'Deep racial hatred and fear that we would seize more territory would unite all the people of Earth in wars against us' (1984: 112). The alternative is extermination. Just as two hundred years in the future, Wells's (1921a: 48) protagonist in The Sleeper Awakes (1899) finds a copy of The Heart of Darkness. See Olaf Stapledon (1999b) on the return of the wiser Martians who invade from the South, overrunning South Africa; Edmund Husserl (2001: 184); and Oliver Morton (2015: 131-2). 
could imagine of the battle of Colenso' (Wells 1901: 159-1260) ${ }^{20}$.

\section{World State}

Wells's vision of world government was an attempt to escape the bloody history epitomised by South Africa: 'We want no more hate in South Africa' (Wells 1917: 193) ${ }^{21}$. Experiment in Autobiography (1934) underlined his commitment to 'the inevitability of a comprehensive world-state, overriding the sovereign governments of the present time' (1967: 209; and see $214-$ 215 ). Only the world-state is able to protect human rights from the predations of capitalism as well as authoritarian states, and contain the destructive tendencies of human nature.

Wells's 1940 publication A Declaration of the Rights of Man, or What Are We Fighting For? anticipated the 1948 Universal Declaration of Human Rights and influenced Jan Smuts's preamble to that document ${ }^{22}$. In his activism, with all its grandiose grousing, Wells saw himself as doggedly realistic, determined not to fall into the fatal idealism of conservatism and

20 The British defeat by the Boers, led by Louis Botha, on $15^{\text {th }}$ December 1899, was part of the British Black Week (Magersfontein, Stormberg and Colenso). Casualties at Colenso were: British 143 killed, 756 wounded and 220 captured; Boers eight killed and 30 wounded.

${ }^{21}$ See Domenico Losurdo (2019: 790) on the importance of 'measures used against blacks in the Southern United States and in South Africa for Hitler's model of 'racial apartheid'. As Bernard Magubane noted: 'The struggle for the liberation of the people of South Africa has always had a global significance' (1986: 23).

22 Wells thought that Smuts was partly responsible for the imposition of dangerously intolerable reparation demands upon Germany after the World War I (see Jean van der Poel 1973a: 94). See R.W.K. Parsons (1983). For his part, writing in 1937, Smuts saw Wells as an impractical idealist with little understanding of the constraints under which politicians make decisions (see Jean van der Poel 1973b: 67). See also Jan Herman Burgers (1992: 464 468); Saul Dubow (2008); and Wilhelm Hendrick Gravett (2015). 'Smuts is one of the best-read men I have met. He seems to know something about everything. He ranges from Joseph Conrad to Kant, from Booker Washington to Tolstoi' (Marcosson 1921: 41). 
radicalism alike, nor into the trough of self-congratulatory but ineffectual reformism.

As Wells explains in The Outline of History, before the 'modern World State' can begin there may be 'tragic economic struggles, grim grapplings, of race with race and class with class. It may be that private enterprise will refuse to learn the lesson of service without some quite catastrophic revolution, and that a phase of confiscation and amateurish socialistic government lies before us' (1920: 14, 504; and see 435-437) ${ }^{23}$. What is clear to Wells is that the age of sovereign nation states is at an end. The World State is to emerge from the infrastructure of the declining British Empire. As early as 1897 he could write: 'The British Empire, like the Roman, was built up by dull men. It may be we shall be ruined by clever ones' (Wells 1897): 65) ${ }^{24}$. By 1914 he could conclude that the empire must be held together by 'unity of language and purpose and outlook' (Wells 1914: 39 ) rather than financial entanglements or more open coercion. Independence within a family of nations will utilise the interconnections formed on the basis of entrepreneurial adventurism and power politics. Rider Haggard noted in his diary:

Yesterday [18 ${ }^{\text {th }}$ November, 1921] I went to town to be the principal guest at the dinner of the Delphian Coterie, where the subject for consideration was 'Quo Vadis - or the Empire a century hence?'. There was a large and enthusiastic audience of a very intelligent order, gathered to welcome my fellow guest, Dean Inge, and myself. Before I spoke the Secretary read out the following remarkable and to my mind most mischievous letter from Mr. H.G. Wells: 'I regret very much that I cannot attend your gathering tonight. I hope and believe that one hundred years hence there will be no British Empire. Either it will have played its part in the development of civilisation and have changed into and given place

23 'The idea of the world state, the universal kingdom of righteousness of which every living soul shall be a citizen, was already in the world two thousand years ago never more to leave it' (Wells (1920): 366).

${ }^{24}$ According to Sydney Olivier (1918: 5), the cause of the trouble was the breakdown of a central authority. 
to a much larger union of free states, or it will have become a danger and a nuisance to mankind, and have followed German Imperialism and Roman Imperialism to the dust heap' (Haggard 1980: 231$232)^{25}$.

Socialism based on 'a resentful consciousness in the appropriated masses of social disintegration' (Wells 1920: 114) provoked by the uncontrolled concentration of property in a few hands correctly identified the problem, but not the solution. The global Marxist revolution cannot be the answer $^{26}$. Indeed, Bolshevism has bought the logical and sensible idea of socialism into disrepute. The Shape of Things to Come (1933) diagnosed Marx's chief fault as 'his insane hatred of the middle classes (bourgeoisie)' (Wells 1935: 140) ${ }^{27}$.

25 "The age of "expansion", the age of European "empires" is near its end' (Wells (1916: 239). Compare Condorcet (2012: 128-129). See also Thomas Milan Konda (2019: 149-160) on the role of Cecil Rhodes and the Round Table.

26 'Marx seems never to have distinguished clearly between restrictive and productive possessions, which nowadays we recognize as a difference of fundamental importance. Exploitation for profit and strangulation for dominance, the radical son and the conservative father, were all one to him ... he betrayed no conception whatever of the real psychology of economic activities, and he had no sense of the intricate organization of motives needed if the coarse incentive of profit was to be superseded' (Wells 1935: 47). Compare what in 1921 the newly founded Communist Party of South Africa (1921) termed 'a New Order, the transition to which will be masterfully controlled by a politically victorious working class'.

${ }^{27}$ The World of William Clissold (1926) accuses Marx of being the prime mover in the destruction of Socialism, turning it into 'an outlet of passionate expression for the inferiority complex of the disinherited' (Wells 1972: 158; and see William J. Hyde 1956). Marx moved away from the 'the simple, essential idea of socialism, which is the abolition of private property in anything but what a man has earned or made' (Wells 1908a: 53). And nationalisation? 'While private adventurers control the political life of the state, it is ridiculous to think of the state taking over collective economic interests from private adventurers' (Wells 1920: 436). Wells described 
Men Like Gods (1923) reflects on the sacrifice of socialism's 'constructive power for militant intensity' in 'the chill of Bolshevik presumption and Bolshevik failure ... this open bankruptcy of a great creative impulse... a victory for reaction' (Wells 1923a: 368). Although that project has failed, there is still hope because 'the Phoenix of Revolution flames down to ashes only to be born again' (368). The ideals persist in what Wells touts as the Open Conspiracy that begins as a movement of discussion, explanation and propaganda, and is 'not so much a socialism as a more comprehensive offspring that has eaten and assimilated whatever was digestible of its socialist forbears' (Wells 1933: 172) ${ }^{28}$. What is to be avoided, according to The Open Conspiracy (1928), is socialism's demonisation of private ownership and the simplification of economic processes 'to the crudity of nursery toys, and the intricate interplay of will and desire in enterprise, normal employment and direction, in questions of ownership, wages, credit, and money ... reduced to a childish fable of surplus value wickedly appropriated' (72). Although bound to be described as Imperialism and regarded as criminal - 'and may have to take grotesque and dangerous forms under the now decaying traditions of national competition' ,- ' '[a]ll the weight of the Open Conspiracy will be 'on the side of world order and against that sort of local independence which holds back its subject people from citizenship of the world' $(86)^{29}$.

Wells initially argued for education rather than revolution:

the question whether the social revolution is, in its extremity, necessary, whether it is necessary to over throw one economic system completely before the new one can begin. I believe that through a vast sustained educational campaign the existing Capitalist system can be civilised into a Collectivist world system; Lenin on

himself as a moderate socialist who looks 'not so much to the abolition of property as to the abolition of inheritance' (1904: 400).

${ }_{28}^{28}$ Men Like Gods: 'the increased dreadfulness of modern weapons was making the separate sovereignty of nations too dangerous to endure' (Wells 1923: 232).

${ }^{29}$ Hence for Claude McKay writing in 1937: 'I said I always thought of Kipling as the bugler of empire, and that perhaps Wells was the sub-officer' (1970: 125). 
the other hand tied himself years ago to the Marxist dogmas of the inevitable class war, the downfall of Capitalist order as a prelude to reconstruction, the proletarian dictatorship, and so forth (Wells 1920: 163$)^{30}$.

In his 1934 interview with Stalin, Wells argued for reformism along the lines of Roosevelt's new deal that (he hoped) would eventually abolish the financial oligarchy. Stalin correctly pointed out that concessions privileging Rockefeller (an organiser) over Morgan (a parasite) merely guaranteed the preservation of the economic basis of capitalism. Wells the reformist deprecated the achievements of the Chartists while Stalin the dictator defended the democratic advances of nineteenth century liberalism ${ }^{31}$. By 1934 Wells was arguing that 'socialist world-state' means 'an adequately implemented Liberal Socialism' (1967: 667-668). Neither violent revolution nor ineffective reform, but revolutionary reform is the answer. 1940 saw Wells, under the heading 'Socialism Unavoidable', arguing against reform of the current capitalist system: 'We have to confront Eastern-spirited collectivism with Western-spirited collectivism .... That full

30 'My country Right or Wrong, the Church, the Party, the Masses, the Proletariat. Our imaginations hang on some such Big Brother idea almost to the end' (Wells 1937: 174). See Wells The New Machiavelli (1910: 83), and Babes in the Darkling Wood (1940). On the disciples of Marx see Wells (1972: 188). 'His [Marx's] proclaimed "social jehad [sic], the class war", "simplified the psychology of the immense variety of people, from masterengineers to stock-jobbers and company promoters whom he lumped together as Capitalists, by supposing it to be purely acquisitive. He made his "Capitalists" all of one sort and his "Workers" all of one sort' (169 - 170). Wells describes his character Clissold as 'a specimen of modern liberalism, using liberalism in its broadest sense' (i). Clissold's father has 'a place in Durban' (224).

${ }^{31}$ See J.V. Stalin (1978: 29 - 31, 41 - 42). See Wells (1939a: 205 - 206; and 88). 'It is not that Marx was profoundly wise, but that our economic system has been stupid, selfish, wasteful, and anarchistic' (Wells 1921b: 86). Wells (1941) compares the Communist Party to the Catholic Church, and argues that Marx imposed an orthodoxy upon the socialist impulse, infecting it with his own conceit, jealousy and arrogance. See Galya Diment (2019). 
and open-eyed collectivisation which ... is the only alternative to the complete degeneration of our species' (1940a: 45, 106) ${ }^{32}$.

It is not surprising that Wells's analysis provoked disdain. In 1922 G.K. Chesterton identified Wells's advocacy of world government with his turn to conservatism, for the World State is to be the United States of the World ${ }^{33}$.

Christopher Caudwell (1938: 22) criticised Wells's 'petit bourgeois

32 'But directly you allow individuals not only to obtain goods for consumption, but also to obtain credit to produce material for types of production outside the staple productions of the state, the question of credit and debt arises and money becomes more complicated. With every liberation of this or that product or service from collective control to business or experimental exploitation, the play of the money system enlarges and the laws regulating what you may take for it, the company laws, bankruptcy laws and so forth increase. In any highly developed collective system the administration will certainly have to give credits for hopeful experimental enterprises. When the system is not collectivism, monetary operations for gain are bound to creep in and become more and more complicated. Where most of the substantial side of life is entrusted to uncoordinated private enterprise, the intricacy of the money apparatus increases enormously. Monetary manipulation becomes a greater and greater factor in the competitive struggle, not only between individuals and firms, but between states' (Wells 1940a: 55).

33 'The attempt of Mr. Wells to make America a sort of model for the federation of all the free nations of the earth, though it is international in intention, is really as narrowly national, in the bad sense, as the desire of Mr. Kipling to cover the world with British Imperialism' (Chesterton 2014: 656). Wells's The World Brain (1938) has him arguing for reconstruction and the steady development of a loyal civil service to his American audience. Wells came to reject the idea of international federalism based on the model of the USA: "The "democracies" of the world are to get together upon a sort of enlargement of the Federal Constitution of the United States (which produced one of the bloodiest civil wars in all history) and then all will be well with us' (Wells 1940a: 89). Are we to incorporate all Western aligned states, even those undemocratic ones? For example, 'the Union of South Africa is a particularly bad and dangerous case of race tyranny' (92). 
reverence for the big bourgeois - the Roosevelt, the far-seeing capitalist visualised as a Samurai', and his utopian dream of the imminent redeemer who will arrive after the complete collapse of the system. Caudwell argued that because Wells lacked necessary faith in the redemptive historical role of the proletariat the change he desired can only come from within the bourgeois class. George Orwell in 1941 identified the immediate problem:

All sensible men for decades past have been substantially in agreement with what Mr. Wells says; but the sensible men have no power and, in too many cases, no disposition to sacrifice themselves. Hitler is a criminal lunatic, and Hitler has an army of millions of men, aeroplanes in thousands, tanks in tens of thousands. For his sake a great nation has been willing to overwork itself for six years and then to fight for two years more, whereas for the common-sense, essentially hedonistic worldview which Mr. Wells puts forward, hardly a human creature is willing to shed a pint of blood (Orwell 1951: 93) ${ }^{34}$.

Campaigning for international human rights, Wells was derided by the British Foreign Office in 1940 as 'a somewhat senile, half-extinct prophet... much better kept at home' (cited in Lauren 2011: 155-156; see also E.M. Forster in Trilling 1965: 173).

However, the criticism of Wells was not simply a by-product of the Realpolitik of World War II. In Heretics (1905) Chesterton observed that ' $\mathrm{Mr}$ Wells exists at present in a gay and exhilarating progress of conservatism,' and pointed to the Boer War as evidence against the identification of world government and perpetual peace: 'For this defiance of the status quo, this constant effort to alter the existing balance, this premature challenge to the powerful, is the whole nature and inmost secret of the psychological adventure that is called man. It is his strength to disdain strength ... [it] is "the policy of Majuba", (Chesterton 2014: 58 - 66) ${ }^{35}$.

${ }^{34}$ On the other side of the political spectrum, in 1941 anti-semite Ezra Pound lambasted 'those who listen to H.G. chubby Wells and the liberal stooges' (Pound 1978: 20; and see 185).

${ }^{35}$ My friend Wouter Jordaan reminds me that the First Boer War's Battle of Majuba Hill, 27 $7^{\text {th }}$ February 1881, yielded the following result: British 92 
The human tendency to thwart and an imperious, over-arching authority will militate against world government. As Chesterton put it in 'Wells and the World State' (1922) the proposition that 'men must abandon patriotism or they will be murdered by science' (2014: 654) will always be resisted. For Chesterton, South Africa provides evidence against the World State $^{36}$. The question of the World State ultimately a question of sovereignty, and accountability. Will global state enhance the self-determination of peoples, nations, and individuals? How, then, did Wells interpret South Africa? Was the turn to what Chesterton calls 'conservatism' and world government - what we would now call, among other things, globalisation influenced by events at this southern peninsula of Africa?

\section{Safrika}

The Passionate Friends (1913) recounts the adventures of one of Milner's Kindergarten, Stephen Stratton, tasked with reconstructing South Africa after the Anglo-Boer War. After the war, having 'won Milner's good opinion ... he was anxious for me to go on working in relation to the labor difficulty that rose now more and more into prominence behind the agricultural resettlement' (1913: 119) ${ }^{37}$. Stratton claims to see through to the heart of reconstruction: '[for] the first time in my life I was really looking at the social fundamental of Labor':

There were, I began to recognize, two sides to civilization; one

killed, 134 wounded, 59 captured; Boers 1 killed, 5 wounded. The British also 'remembered Majuba' (Wells 1940a: 12).

${ }^{36}$ See Chesterton, 'The Future of Democracy' (1920: 695-696). As for Chesterton's own monsters: 'When I was a child I have stared at the darkness until the whole black bulk of it turned into one negro giant taller than heaven' (Chesterton 2000: 313). Orthodoxy (1909): 'What could be better than to have all the fun of discovering South Africa without the disgusting necessity of landing there?' (2014: 182).

${ }^{37}$ Wells's New Worlds for Old: A Plain Account of Modern Socialism (1912) opens with an approving epigram from Lord Milner. By 1913 South Africa was the largest producer of gold in the world (Rönnbäck \& Broberg 2019: 383). 
traditional, immemorial, universal, the side of the homestead, the side I had been seeing and restoring; and there was another, ancient, too, but never universal, as old at least as the mines of Syracuse and the building of the pyramids, the side that came into view when I emerged from the dusty station and sighted the squat shanties and slender chimneys of Johannesburg, that uprooted side of social life, that accumulation of toilers divorced from the soil, which is Industrialism and Labor and which carries such people as ourselves, and whatever significance and possibilities we have, as an elephant carries its rider (Wells 1913: 120).

South Africa reveals a profound truth:

It was all so nakedly plain there. On the one hand was the primordial, on the other the rankly new. The farm on the veld stood on the veld, a thing of the veld, a thing rooted and established there and nowhere else. The dusty, crude, brick-field desolation of the Rand on the other hand did not really belong with any particularity to South Africa at all. It was one with our camps and armies. It was part of something else, something still bigger: a monstrous shadowy arm had thrust out from Europe and torn open this country, erected these chimneys, piled these heaps - and sent the ration-tins and cartridge-cases to follow them. It was gigantic kindred with that ancient predecessor which had built the walls of Zimbabwe. And this hungry, impatient demand for myriads of toilers, this threatening inundation of black or brown or yellow bond-serfs was just the natural voice of this colossal system to which I belonged, which had brought me hither, and which I now perceived I did not even begin to understand (Wells 1913: $122-123)^{38}$.

${ }^{38}$ Milner assured that there was 'no question of the black population ever becoming a danger to the supremacy of the whites' (cited in Marlowe 1976: 187). It seems that the importation of Chinese labour into South Africa was considered by the Chamber of Mines as early as 1898. Post Boer War plans were shaped by the experience of the USA, Canada, and Australia but the main local consideration was the attitude of the Transvaal whites to the Indians in their midst and the determination of Milner to prevent the 
The key question was economic development that would ultimately benefit all, and those best able to move the economy along that path were white (and British) ${ }^{39}$. For the present blacks were to supply the labour. For the liberal imperialist ' $[\mathrm{h}]$ ere in the great ugly mine-scarred basin of the Rand' (120) the traditional, immemorial homestead and the ancient accumulation of toilers divorced from the soil are the two sides of civilisation.

What Stratton sees in South Africa is a variation of what Wells in The Outline of History (1920) calls 'this new wealth of industrial capital' and 'the small cultivators and peasants, ruined and dislodged by the Enclosures Act' (1920: 378) indicative of English development. This narrative of development away from the primordial homestead is part of a global process concerning,

the type of household which has prevailed in human communities since Neolithic days, which still prevails to-day in India, China, and the Far East, but which in the west is rapidly giving ground before a state and municipal organization of education and a largescale industrialism within which an amount of individual detachment and freedom is possible, such as these great households never knew (Wells 1920: 181).

emergence of a white proletariat in the Transvaal (see Campbell: 1923: 170 173). 'On March 21 [1904], Henry Campbell-Bannerman moved a vote of censure on Mr. Balfour's government. The subsequent debate was vigorous. The government had promised smiling homes for British families in the Transvaal as soon as the "semi-barbarous civilization and effete government of the Boers" had been swept away. They were now faced with the fiasco of having conquered a country which they could not colonize' (Campbell 182). Balfour replied to the jibe that he was in favour of importing servile labour by pointing out that it was Liberal Ministers who had been responsible for the introduction of Indian labourers into the West Indies (see 205).

${ }^{39}$ For the troubled Mr. Brumley the 'acute disillusionments that arose out of the Boer War' meant that '[t]he first decade of the twentieth century was for the English a decade of badly sprained optimism. Our Empire was nearly beaten by a handful of farmers amidst the jeering contempt of the whole world - and we felt it acutely for several years' (Wells 1915: 292 - 293). 
The Milnerite narrator of The Passionate Friends cannot see the connection between the primordial homestead and the rankly new industry. Or rather, they are related but distinct; differentiated by time (see Marks \& Trapido 1979).

Of course the homestead conceived as a stable social reality, the basic unit of economic production and social reproduction, anchored outside of modernisation is a myth (see Mike Morris 1976 \& 1987). It is an important myth of settler ideology for the primordial right of the household society presupposes nothing less than the ownership of land as the basis of independence and freedom ${ }^{40}$. By the end of the year which saw the publication of The Passionate Friends, the piece of social South African engineering that was the 1913 Native Land Act attempted to reduce competition by African peasant producers and extrude labour onto the market.

South African primitive accumulation and agricultural development took place within a context shaped by industrial capital that was already finance capital. There is no agricultural production beyond the reach of the market (see Keegan 1990: 207; and Wallerstein 2000: 244) ${ }^{41}$. The idea of the primordial farm distinct from rankly new industry is itself an ideological secretion of the system that enables the criticism of industrial finance capitalism from within its shelter. The fabrication of the primordial was part of the colonial process, and part of the broader movement of the world system $^{42}$. Wells reveals the New Imperialists of the British Empire as old-

${ }^{40}$ Lenin on the theory of non-capitalist agriculture in a capitalist society: 'It is no exaggeration to say that this theory is an illusion, a dream, under which the whole of bourgeois society is labouring' (Lenin 1964: 18). In his conversations with Lenin, Wells concurs that '[t]he peasant method of life was to be fought and beaten in detail, first here and then there' (Wells 1932: 180). The peasant 'is the basis of the old order and a misfit and anachronism in the new .... Essentially the modernization of food production means the supersession of this small localized self-directing cultivator, peasant or peasant-like' (Wells 1932: 177, 179).

41 "'Africa", said some visitors, but others, less travelled or more imaginative, said, "This might be in some other planet, in Mars or in the Moon"' (Wells: 1927: 72).

42 'In breaking down the pre-capitalist framework of society, capitalism thus broke not only barriers that impeded its progress but also flying buttresses 
fashioned colonists imposing an alien and alienating global power. Only they cannot see their plans for improvement for what they truly are ${ }^{43}$. Which does not mean, for Wells, that such a path of development is not necessary. With this in mind, the question that lurks in Wells's meditation is: given that such experts are the elite who guide change, how can world government possibly overcome, rather than repeat, the ills of the past? ${ }^{44}$ Who will educate the educators?

In Men Like Gods the Liberal protagonist has lost faith in the League of Nations and fears 'some sort of financial and economic crisis' (1923a: 193). Transported from 1921 into a parallel dimension he and his companions find themselves in an advanced civilisation that has overcome the problems that beset us. The place they name Utopia has come from the same dark place that mires earthlings. They learn that the prerequisite of escaping the Age of Confusion was 'the beginnings of world-wide political

that prevented its collapse. That process, impressive in its relentless necessity, was not merely a matter of removing institutional deadwood, but of removing partners of the capitalist stratum, symbiosis with whom was an essential element of the capitalist schema' (Schumpeter 2003:139).

${ }^{43}$ See Wells (1930: 76 - 77; and 1908b: 28). 'The British Empire in his [Lord Edensoke's] eyes was a fine machine for utilising the racial instincts of the serviceable British peoples for the enforcement of contracts and the protection of invested capital throughout the world. If they did not, as a general rule, get very much out of it in spite of their serviceableness that was their affair' (Wells 1927: 245 - 246).

44 'The first most obvious danger of Africa is the militarization of the black. General Smuts has pointed this out plainly. The negro makes a good soldier; he is hardy, he stands the sea, and he stands cold. (There was a negro [Mathew Henson] in the little party which reached the North Pole.) It is absolutely essential to the peace of the world that there should be no arming of the negroes beyond the minimum necessary for the policing of Africa' (Wells 1918a: 42). 'A bacterium that may kill you or me in some novel and disgusting way may even now be developing in some Congo muck-heap. So here is the need for another Commission to look after the Health of Africa' (44). This is part of Wells's case for the League of Nations Health Organisation which was set up in 1923 and incorporated into the World Health Organization (WHO) in 1948 (see Borowy 2009). 


\section{Shane Moran}

unity' for only then could 'world resources and world production' (349) be known and organised. The disorders and indignities of the Age of Confusion include '[a]n overwhelming system of debt, a swarm of creditors, morally incapable of helpful renunciation, crushed out all fresh initiative' (229 230). Politics was the bridge "towards international charity and the liberation of their economic life from a network of pretences, dishonesties and impostures' (368). Politics has led the way out of politics, but only by way of the criminalisation of lying, and commitment to 'Free Discussion and Criticism' $(348)^{45}$. In Utopia reason rules: 'Our education is our government' (235). Which might also be read as: our government is our education! Utopia's transformative agenda has produced one planetary state rather than a free union of states.

The end result is a high-tech Spartan Utopia run along anarchistic socialist lines, reaping the fruits of discriminating eugenics (directive breeding): 'There had not been even a general admixture of races. On Utopia as on earth there had been dusky and brown people and they remained distinct. The various races mingled socially but did not interbreed very much' (341). With money abolished and production organised, technocracy and 'no central government' (225) combine economic efficiency with economic dependency. 'The transmission is wireless' and '[e]very one was indexed and noted' (345). All is well until visitors from earth arrive:

For more than twenty centuries the Utopians had had the completest freedom from infectious and contagious disease of all sorts. Not only had the graver epidemic fevers and all sorts of skin diseases gone out of the lives of animals and men, but all the minor infections of colds, coughs, influenzas and the like had also been mastered and ended. By isolation, by the control of carriers, and so forth, the fatal germs had been cornered and obliged to die out ... Utopia was even less prepared for the coming of these disease

45 The New World Order: '(a) outright world-socialism scientifically planned and directed, plus (b) a sustained insistence upon law, law based on a fuller, more jealously conceived restatement of the personal Rights of Man, plus (c) the completest freedom of speech, criticism and publication, and a sedulous expansion of the education organisation to the demands of the ever-growing demands of the new order' (1940a: 119). 
germs than for the coming of the Earthlings who brought them (Wells 1923a: $283-284)^{46}$.

Amidst the epidemic some of the earthlings see the possibility of utilising their immunity to subjugate Utopia: 'we must consider ourselves a colony, a garrison' (299). Not all of the potential colonists confined to Quarantine Crag agree, not least because of the perceived asymmetry of power: 'We are like a handful of Hottentots in a showman's van at Earl's Court, planning the conquest of London' $(295)^{47}$. But, it seems, we humans cannot resist the temptation to exploit a crisis: 'These are panic measures. The pestilence is only in its opening stage. Everything is just beginning. Trust me' $(290)^{48}$. Fortunately, the earthlings are not in a position to offer salvation and blackmail to the Utopians in the form of a vaccine.

46 'Animals may survive by devastation. They may also survive by carrying some disease in a mitigated form that will exterminate other species. No need to outshine or defeat a more energetic race. They may waste or stink out of existence' (Wells 1923b: 171). For the classic and all too familiar imagery of disease see Book 2 of Thucydides, The Peloponnesian War (1954: 123 127). In The Outline of History Wells refers to the plague of Athens in the context of the death of Pericles.

47 Wells's racism is often interwoven with that of his narrating dramatis personae: 'Hundreds of deeply preoccupied Negroes pranced and flung themselves about in the Southern Sunshine in search of a real Martian Newstep' (Wells 1937: 137). Compare Wells's 'The Lord of the Dynamo', (1894) with Kafka's 'In the Penal Colony' (1919): 'Then the black grasped him again, putting a curly head against his chest, and they swayed and panted as it seemed for an age or so. Then the scientific manager was impelled to catch a black ear in his teeth and bite furiously. The black yelled hideously' (Wells 1904a: 211). Later Wells declared: 'Suppose we drop that old cant about politically immature peoples' (1940a: 95).

${ }^{48} \mathrm{Mr}$. Rupert Catskill, the would-be putschist of Men like Gods, probably represents Winston Churchill, of whom Wells wrote in December 1944: 'The British Prime Minister's mind is dull only in its phases of relaxation, but it is now plainly in a phase of extreme reaction, entirely preoccupied with the petty enterprises of his own antiquated career. His ideology, picked up in the garrison life of India, on the reefs of South Africa, the maternal home and 
In Men like Gods the small farms epitomised by South Africa under reconstruction that featured so prominently in The Passionate Friends are gone. Now it is 'as if the whole place were a garden' (213). Significantly, the only view of Utopian agriculture is from a distance, an elevated 'parapet' (367), and there is no mention of colonisation in Utopian history. It would seem at first sight as if the history condensed in South Africa is erased, buried in the Great Confusion, and superseded by politico-technological progress. Labour is invisible and rendered frictionless in the mist of 'universal gracious amenity' (369), and the substitution of large-scale business for the multitude of small scale businesses is a stage that is erased ${ }^{49}$. The economic system that facilitated industrial progress has given birth to 'a perfected landscape' (366): 'The ages of economic disputes and experiments had come to an end; the right way to do things had been found' $(287)^{50}$.

However, Wells cannot be so easily cast as a naïve utopianist. Guarded by Utopians 'in gas masks' (291), in '[t]he shadow of the great epidemic' (283) the earthlings are flown to their quarantine:

They crossed a rather thickly inhabited, very delightful-looking

the conversation of wealthy Conservative households, is a pitiful jumble of incoherent nonsense' (cited in Wagar 1964: 366).

49 'The development both of extensive proprietary companies and of government departments with economic functions has been a matter of the last few centuries, the development, that is to say, of communal, more or less impersonal ownership, and it is only through these developments that the idea of organized collectivity of proprietorship has become credible' (Wells 1933: 34). 'Countless people ... will hate the new world order, be rendered unhappy by frustration of their passions and ambitions through its advent and will die protesting against it' (Wells 1940a: 170).

50 "II must confess", [Mr. Burleigh] said, "that I am most interested in the peculiar form of Anarchism which seems to prevail here. Unless I misunderstand you completely every man attends to his own business as the servant of the state. I take it you have - you must correct me if I am wrong a great number of people concerned in the production and distribution and preparation of food; they inquire, I assume, into the needs of the world, they satisfy them and they are a law unto themselves in their way of doing it" (Wells 1923a: 227). 
coastal belt and came over what was evidently a rainless desert country, given over to mining and to vast engineering operations ... For a time the Earthlings were flying over enormous heaps of slaggy accumulations, great mountains of them, that seemed to be derived from a huge well-like excavation that went down into the earth to an unknown depth. A tremendous thunder of machinery came out of this pit and much smoke. Here there were crowds of workers and they seemed to be living in camps among the debris. Evidently the workers came to this place merely for spells of work; there were no signs of homes (Wells 1923a: 291).

It is Wells's focaliser, Barnstaple the liberal news-paper editor, though whose eyes we see that 'people could work and struggle for loveliness' (286) in the Edenic gardens of Utopia. It is he who sees through a 'haze' that edits out the struggle that is inseparable from progress: 'He had always thought of Utopia as a tranquillity with everything settled for good' (287). The possibility that Utopia is built on the exploitation of labour so striking in South Africa is glimpsed fleetingly by the well-meaning liberal. The vision of small farms as productive homesteads, the rankly new, looks very much like the ideologically loaded settler home standing on the South African veld; the ancient predecessor is reborn with all mod cons, the horror of brutal coercion and resistance erased. Neither the narrator of Men Like Gods, nor his central protagonist, makes this connection. It is left to the reader to read Wells better than he read himself.

However, the Wellsian gravedigger of agglomerative corporations does not remain totally invisible, submerged in a mixture of processes and proclivities, veiled under the final result of an administered anarchistic society with privacy without private property 'in all but very personal things' $(226)^{51}$. The Utopians explain:

51 'There was hope and dismay everywhere in the world in 1919 .... There might actually be a world government which wouldn't so much "broaden out" from existing governments, as push them aside and eat them up .... And equally there might really be a new sort of economic life coming into existence. We might find ourselves positive, participating shareholders in a one world business, and all our individualism gone .... Population might really be stanched and controlled. It was no dream. It was hard for most 
The old order gave small rewards to the schoolmaster, but its dominant types were too busy with the struggle for wealth and power to take much heed of teaching: it was left to any man or woman who would give thought and labour without much hope of tangible rewards, to shape the world anew in the minds of the young. And they did so shape it. In a world ruled ostensibly by adventurer politicians, in a world where men came to power through floundering business enterprises and financial cunning, it was presently being taught and understood that extensive private property was socially a nuisance, and that the state could not do its work properly nor education produce its proper results, side by side with a class of irresponsible rich people. For, by their very nature, they assailed, they corrupted, they undermined every state undertaking; their flaunting existences distorted and disguised all the values of life. They had to go, for the good of the race (Wells 1923a: 233 - 234).

Education is the $\mathrm{key}^{52}$. And so is depopulation. In the Last Age of Confusion the population of Utopia reached two thousand million (two billion), and had been reduced to two hundred and fifty million ( $88 \%$ reduction): 'the maximum population that could live a fully developed life upon the surface of Utopia. But now with increasing resources the population was being increased' (229). The problem with overpopulation was that people 'swamped every effort the intelligent minority could do to educate a significant proportion of them to meet the demands of the new and still

people to decide whether this was to be treated as a mighty dawn or the glare of the last conflagration .... We were living in a period of panic and short views both ways' (Wells 1927: 304 - 306).

52 Wells has one of his pro-imperialist characters claim that colonial education provides a model of what can be achieved: 'What is education in England up to, anyhow? In Uganda we knew what we were doing. The Old native tradition was breaking up' (Wells 1918b: 218). By 1934 Wells could argue: 'The British Empire, I said, had to be the precursor of a world-state or nothing .... Its essential unity must be a unity of great ideas embodied in English speech and literature' (1967: 652). See also Leonard Woolf (1920: 101). 
rapidly changing conditions of life' $(229)^{53}$. The prerequisite of progress is population reduction, viewed (by the survivors, of course) as a price worth paying.

After the attempted coup, the earthlings are ejected from Utopia: 'We might end by exterminating you' (359), they are told. Clearly the world is not to be set right by argument or education alone. It is the liberal gaze that blurs the sublation of capitalism and the necessary fight for freedom, a perspective that Wells both shares and criticises ${ }^{54}$. The problems are clear, but how to resolve them, either within the current system or via a radical alternative, is not ${ }^{55}$. Wells advocated for the latter, but with the failures of

53 'Mr. Burleigh turned to the Utopian again. "That is extremely interesting", he said. "Even at present our earth contrives to carry a population of at least five times that amount"' (Wells 1923a; 229). "Upon this festering, excessive mass of population disasters descended at last like wasps upon a heap of rotting fruit. It was its natural, inevitable destiny. A war that affected nearly the whole planet dislocated its flimsy financial system and most of its economic machinery beyond any possibility of repair. Civil wars and clumsily conceived attempts at social revolution continued the disorganization. A series of years of bad weather accentuated the general shortage. The exploiting adventurers, too stupid to realize what had happened, continued to cheat and hoodwink the commonalty and burke any rally of honest men, as wasps will continue to eat even after their bodies have been cut away. The effort to make passed out of Utopian life, triumphantly superseded by the effort to get. Production dwindled down towards the vanishing point. Accumulated wealth vanished. An overwhelming system of debt, a swarm of creditors, morally incapable of helpful renunciation, crushed out all fresh initiative.' (230)

54 'That Pax Mundi will not be any sort of repressive peace. Why should it be? At a certain stage - in the mental treatment of our world, there may have to be a certain amount of fighting and killing, police hunts for would-be dictators and gangsters, and so forth, but I doubt if intelligences more and more able to control the genes will need to eliminate undesirable types by force' (Wells 1937: 190; and see Wells 1940a: 170).

${ }^{55}$ Chesterton in 1922: 'This argument amounts to saying, first that the World State will be needed because it is strong, and then that it may safely be weak because it will not be needed' (2014: 656). 
Soviet Communism and the pitfalls of Nazism before him foresaw world government as the least invidious alternative.

\section{Open Conspiracy}

Today claims for world government are part of the analysis of globalisation and what has been called 'post-politics' (Žižek 1999: 30). We are assured that '[d]angerous, labour-intensive extraction processes will transition to safe, remote monitoring of equipment' (Deloitte 2018: 3). Production digitisation and networking of self-optimising production machines and intelligent products are to combine with cyber-physical systems. Klaus Schwab:

The fourth industrial revolution has the potential to robotize humanity, and thus compromise our traditional sources of meaning - work, community, family, identity. Or we can use the fourth industrial revolution to lift humanity into a new collective and moral consciousness based on a shared sense of destiny. It is incumbent on us all to make sure that this latter is what happens (Schwab 2016: 134).

Those promoting 'a true global civilization' (134) see the challenge of Industry 4.0 as consisting of destiny and moral consciousness. What is required is trust: 'we face a terrible lack of trust' (United Nations 2017: 2).

We are back to familiar Wellsian topography of historical turning points and centralisation of power ${ }^{56}$. Does technological development privilege multi-national corporations over accountable state politics? Will things be better when the Great Powers are replaced by One Power? Who

${ }^{56}$ And back to the contradictions of a world federation of states elaborated by Immanuel Kant: 'Although this political body exists for the present only in the roughest of outlines, it nonetheless seems as if a feeling is beginning to stir in all its members, each of which has an interest in maintaining the whole. And this encourages the hope that, after many revolutions, with all their transforming effects, the highest purpose of nature, a universal cosmopolitan existence, will at last be realized as the matrix within which all the original capacities of the human race may develop' (Kant 1991: 51). 
controls, and profits from, the New World Order? ${ }^{57}$ Who is accountable in this era of post-politics and its 'sort of fairy-tale plausibility' (Wells 1937: 77)? If Wells's touted 'western-spirited collectivism' (1940a: 81), 'a liberal triumph over the dogmatism of the class war' (88) and 'a change in directive ideas' (112) tdegenerated into pleas for a mystical awakening, it has left its mark on the global institutions of today ${ }^{58}$. And so too has his fear of global domination and recolonisation whereby we become human raw material to be put at the disposal of superior beings and their creations. Beyond the conspiracy that there is no conspiracy, perhaps those who are so cold blooded are not human (see Zwiggelaar 2012) ${ }^{59}$.

Universalise the key principle of colonialism (resource extraction; expendable natives) and you arrive at alien invasion and world domination:

${ }^{57}$ Recall the Boer War as pretext for the massive transfer of wealth from public coffers to private investors: 'When peace was finally declared on 31 May 1902, investors in South African gold companies [listed on the London Stock Exchange] had earned a nominal accumulated return on investment of 64 per cent relative to September 1899, that is, prior to the outbreak of the war. Investors in South African financial companies (heavily involved directly and indirectly in the mining business) made even larger gains, earning a nominal return on their investments of 100 per cent relative to the pre-war level of September 1899. Given the low rate of inflation in these years, the average real annual rate of return translated into 8 per cent per year for South African gold-mining companies and 17 per cent per year for investments in South African finance companies. These private gains at an enormous cost to the British Treasury, which had to foot the $£ 217$ million bill for the massive military intervention as well as to more than 20,000 dead British soldiers' (Rönnbäck and Broberg 2019: 320).

${ }^{58}$ Wells's irony is designed to indicate a self-reflection that his characters lack: 'Mr. Sempack left his politics and economics; the sure hope of the One World State and the One World Business floating benevolently in their mental skies .... "We have got clear to the conception of a possible world peace, a world economic system, a common currency, and unparalleled freedoms, growths and liberties" (Wells 1927: 38, 191).

59 According to Al Gore, the current crisis has the potential 'to move the world in the right direction' (cited in Goode \& Rogers 2020). In Fredric Brown's 'Sentry' (1954) the aliens are humans. 
'humanity undergoes - dehumanization' (Wells 1937: 89) ${ }^{60}$. Echoing Wells's science fictions, the ghost of colonialism haunts those feeling powerless before technology and its controllers ${ }^{61}$. As Zulu Shaman Credo Mutwa put it: if the dictators (Chitauri) are not even human, who controls the controllers ${ }^{62}$ Has the open conspiracy mutated into an anti-human agenda that recalls the contradictions of the colonial economy: 'They are experimenting with human mutations' (Wells 1937: 79)? If colonialism is the way of history, why should our future be any different from the past (see Project for the New American Century 2000; and see Pilger 2002)? Who would want to enslave humanity and destroy the world economy: 'A sort of massacre of small and independent businesses' (Wells 1940a: 78)? When the independent producer (primordial or otherwise) is being undermined, cui bono?

It is worth noting that the projection of the non-human antagonist is eminently rational, according to Kant, and accords with the possibility that reason is not limited to human beings. To assume anything else is to presume that we are the only rational creatures or that other rational creature's reason like us. It is substitute habit for cognition 'in a way similar to animals': 'For merely because we are not familiar with rational beings other than the human being, we would have a right to assume them to be constituted just as we cognize ourselves to be, i.e., we actually would be familiar with them' (Kant

60 'The first characteristic of these [colonialist] norms, is that the subhumanity of the indigene is not an objectively detectable fact, but a value to be maintained. And super-exploitation ... is a categorical imperative: "Act in such a way that you always treat the indigene as an inessential means and never as an end"' (Arthur 2010: 143, quoting Sartre, 'Rome Lecture', 1964). 61 'Earlier colonialists came by boats to 'the new world' and expanded their empires by building railroads, farms and infrastructure. Today's colonialists are digital; they implement communication infrastructures such as social media in order to harvest data and turn it into money' (Lehohla 2018). See Branko Milanovic (2019).

${ }^{62}$ See Credo Mutwa on reptilian-extraterrestrials, and David Icke (2004) on the Reptilian Agenda; and David Chidester (2002: 65-85). At the time of writing, Icke's interviews with Mutwa are still available on Youtube. Icke's recent criticism of the World Health Organisation have led to him being deleted. 
1996: 146). To assume that other rational beings lack 'a different way of presenting [Vorstellungsart: picturing]' is to propose 'that our ignorance would render us greater services for expanding our cognition than any meditation' (146). According to the reptilian hypothesis, they are rational but anti-human, and their rationality seems psychopathic from our point of view. The prospect of our expendability confirms the psychopathology of those lacking empathy and remorse (see Kipniss 2013). Picture us as the hunted animal contemplating its predators, as the animal views carnivorous man, and the lizard hypothesis does not appear so irrational.

When the inhumanity of the system is projected onto its beneficiaries, the rest of us, except for the collaborators, are left in the position analogous to that of the colonised: 'a sense of dethronement, a persuasion that I was no longer a master, but an animal among animals, under the Martian heel. With us it would be as with them, to lurk and watch, to run and hide; the fear and empire of man had passed away' (Wells 2012: 151) ${ }^{63}$. If alien invasion is the exception that proves the rule, then anti-colonial struggles can provide some guidance when colonialism is the mythos that best captures spectacle of non-human force manipulating human society ${ }^{64}$.

But there is a potential problem with this analysis. Seeing oneself in the position of the colonised might entail sympathy with the victims of colonialism. It also vindicates colonialism in so far as the framework of colonial relations is naturalised: colonise or be colonised! The War of the Worlds:

And before we judge of them [the Martians] too harshly we must

63 'The world of Eloi and Morlocks is revealed first as devolutionary and then as one of predator and prey, of homo homini lupus. This must have a political, not merely a biological significance. No society, Wells is saying, can escape the brutish aspects of human nature defined by classical bourgeois rationalists such as Machiavelli and Hobbes' (Parrinder 1976: 272). Indeed, as a visitor to the future read in a newspaper: 'The observations made in the interior parts of Africa, correspond exactly with ours' (Mercier 1772: 217).

64 'If "[d]isintegration of the existing world economic system is order of the day", then "[d]e-colonisation is not merely a movement against political dependence; it is turned against economic dependence as well"' (Bonn 1934: 847, 846). 
remember what ruthless and utter destruction our own species has wrought, not only upon animals, such as the vanished bison and the dodo, but upon its inferior races. The Tasmanians, in spite of their human likeness, were entirely swept out of existence in a war of extermination waged by European immigrants, in the space of fifty years. Are we such apostles of mercy as to complain if the Martians warred in the same spirit? $(2012: 5)^{65}$.

Is it primarily a question of the intentions of those in control of technology; a question of manipulation and use? ${ }^{66}$ Is technology neutral? Or is there something essential to technology that lifts instrumentalism into a totalising metaphysic that threatens the human (see Heidegger 2019)? Does organisation mean centralisation and uniformity - what has been called 'cultural genocide' (Pasolini 1987: 112) - or worse? ${ }^{67}$ Who doubts the imperiousness of those intent on attaining power? ${ }^{68}$ That is to say, as the words of the Haitian Creole translation of The Time Machine has it, are things

65 See John Rieder on ' $[\mathrm{t}]$ he Wellsian strategy [of] reversal of positions [coloniser-colonised] that stays entirely within the framework of the colonial gaze and the anachronism of anthropological difference, but also highlights their critical potential' (2008: 10); Suvin (1979: 208); Jameson on the 'patently a guilt fantasy' of the beneficiaries of colonialism (2005: 265; and p.339); and Rieder (2009: 86).

66 'First we've got population. The world today has 6.8 billion people - that's headed up to about 9 billion. Now if we do a really great job on new vaccines, health care, reproductive health services we could lower that by perhaps ten or fifteen per cent' (Gates 2010: 443-449). It seems that Bill Gates may have had in mind the reduction in the reproduction of children that appears to follow from improved health. For a different interpretation see Skouras (2020). ${ }^{67}$ See Lenin on imperialism as 'the dream of idealistic politicians, the United States of the civilized world' and the early twentieth century revolt of the Herero's in South West Germany and the uprising of the Hottentots (Lenin 1968: 684, 682; emphasis in original).

68 'But now we are beginning to realise that, for any revolution to succeed, there must be this core of special intelligence, of enlightened fanatics, so to speak, whose minds are liberated enough to imagine a new order ... the specialised backbone' (Wells 1940b: 71). 
to remain the same: 'Ou ka imajine ki jan tout kalm mwen disparèt. Brutes yo ti fèmen sou mwen' (Wells n.d., n.p.)? ${ }^{69}$

The key, of course, is context and the capacity of the anti-colonial paradigm to address the question of sovereignty (of the oppressed, the marginalised, the exploited, the colonised) digested by the supra-sovereignty of a universal cosmopolitan existence. Wells's grappling with the idea of that World State reveals that proponents of globalisation can easily take this supposed radical departure in their stride with the promise of inclusivity and universal benefit. A supra-national one world order - 'post-nation state, worldwide, universalizing-without colonizing redress of most of the wrongs of history' (Brown 2009: 122) 70 $^{-}$will transcend the partiality and competitiveness of colonialism/ imperialism in the name of humanity. Globalisation is decolonisation by way of Wellsian technological innovation and integration (rationalisation), conflict resolution leading to planetary commity (perpetual peace), and denationalisation ${ }^{71}$. Resistance to a world enveloped by one promising global economic system is readily dismissable as reactionary nationalism, nativism, racism, anti-cosmopolitanism, fighting against progress toward a world republic; selfishness, futile short-sighted, etc ${ }^{72}$. It is in this spirit that Žižek, invoking Wells's The War of the Worlds, sees an op-

${ }^{69}$ In English: 'You may imagine how all my calm vanished. The little brutes were close upon me' (Wells 1995: 81). See Wells's comment on Haiti (1922: 259).

${ }^{70}$ Brown is criticising the feasibility of this vision of globalisation subject to globalising capital.

71 'Moreover, the production of agricultural produce in Africa, which mostly depends on small peasant households, can no longer compete in the world market with more efficient capitalist production of the same produce elsewhere. Wages are low in Africa, but so is the productivity of labour. Higher productivity on mechanized farms elsewhere ruins the African peasant. This means that he is not exploited by neocolonialism but marginalized by the forces of the world market' (Rothermund 2006: 272). 'It was of course easily believed that unemployment, far from being due to the decline of capitalism, was due to the worthlessness of the pariahs' (Stapledon 1999a: 32).

72 'For it is often precisely in the name of the universality of human rights, or at least of their perfectibility ... that the indivisible sovereignty of the 


\section{Shane Moran}

portunity in the current crisis that signals 'the urgent need for a reorganization of the global economy which will no longer be at the mercy of the world market' (Žižek 2020: 44). To understand what he means by the opportunity to reinvent Communism, Žižek quotes with approval WHO chief Dr. Tedros Adhanom Ghebreyesus, and concludes: 'The coronavirus epidemic does not signal just the limit of the market globalization, it also signals the even more fatal limit of nationalist populism which insists on full state sovereignty' $(68)^{73}$. Are Left and Right converging under the banner of liberal globalisation?

Then as now everything hinges on distinction between international control, world government and imperialism: who controls the controllers of the agenda ${ }^{74}$ Who would want to destroy small and medium businesses, and institute a cashless society that will undermine national sovereignty? Undermine the autonomy of national currency and you undermine national sovereignty in the name of the sovereignty of humanity and the decolonisation of the political. Is the failed state, then, a prerequisite of progress? How can even Wellsian 'Westernised World Socialism' (Wells 1939: 56) not appear and function as colonialism? Recall that in Wells's

nation-state is being more and more called into question ... (Derrida 2005: 157).

${ }^{73}$ Kristalina Georgieva (2020), Managing Director, IMF, also sees 'some tremendous opportunities'.

74 'Let the Reds fade out. Martians! People will hate them from the word Go!' (Wells 1937: 150). 'We've been barking up the wrong tree. These reds - Moscow - Bernard Shaw - New Dealers - Atheists - Protocols of Zion, all of that - mere agents. It's Mars that is after us. Listen to him. Mars! What are we to do about it? What are we to do?' $(143-144)$. For anti-semite Nesta H. Webster, Wells's World State played into the hands of the Illuminate (Webster 1924: 336). See Wells's inside exploration of anti-semitism in The Holy Terror (1939). The conspiracy-driven dictator may be necessary: ' $\mathrm{He}$ ended war for ever. He did. He rationalised property and money. He inaugurated the Age of Plenty. He reconstructed world education'; but ultimately he too will become '[j] ust a memorial of reptilian energy, vestiges of a slobber in the mud' (Wells 1939b: 440). For his part Wells argued that conspiracy theorists like Webster are important and must be read and debated, not merely dismissed (see Wells 2016: 42-49). 
cosmopolitanism with a vengeance all the weight of the Open Conspiracy will be 'on the side of world order and against that sort of local independence which holds back its subject people from citizenship of the world'. According to Wells's vision of social democracy in a state of globalisation a responsible world directorate serving the common ends of humanity will oversee the substitution of large-scale business for the multitude of small scale businesses ${ }^{75}$. On the other hand, declarations of human rights and commitment to freedom of speech require enforcement. When censorship becomes the norm, we need to ask who benefits: 'How far is our intellectual freedom here still ours only because, as a matter of fact, we are too discreet to exercise it?' (Wells 1937: 167 - 168).

Amid 'chains of suspicion, and the technological explosion' (Cixin 2016: 7$)^{76}$ the planetary allegory of colonialism, mixing retribution and paranoia, strikes a chord today and indicates the felt balance of power. Those working for freedom face an aristocracy of vested interests: 'They had better summon up their resolution' (Wells 1940a: 191). The coordinates of colonialism as world unification provide a cognitive map for globalisation with humans as standing-reserve, a resource to be used or discarded, effecttively subject alien intention: 'man, an ephemerid, coming to life for a moment' (Tolstoi 1950: 47). If fear of the 'progressive enslavement of the race' (Wells 1935: 46) is the preserve of a fringe reaction, it is not without precedent. While we may not need aliens or lizards to explain how ideology works $^{77}$, the prevalence of censorship and misinformation may signal a species wide (i.e., global) power struggle: 'This avoidance of fundamental

${ }^{75}$ For a restatement of this type of Wellsian optimism see Paul Mason (2019). ${ }^{76}$ But isn't South Africa a precedent for realisation of benign technologism or socialised technology? Did not pharmaceutical companies (admittedly under pressure) renounce their patent rights for AIDS drugs? 'The ultimate crisis that Earth is now facing means that open technology is the unavoidable responsibility that advanced countries have to all humanity' (Cixin Liu 2016: 40). Will we be able to say the same about the COVID-19 crisis?

77 'But we do not need aliens or secret drugs or glasses - the form of ideology does the work without them' (Žižek 2009). Žižek is referring to John Carpenter's film They Live (1988), inspired by Ray Faraday Nelson's 1963 'Eight O'Clock in the Morning' (Nelson 1975) in which Kate Blake gives birth to a hybrid human-lizard amid the conflict with Urizen. 
criticism is one of the greatest dangers to any general human understanding' (Wells 1940a: 49) ${ }^{78}$.

Are we witnessing the intellectual unification that Wells prophesied, or the descent into confusion and suspicion that precedes world war? And if there is no intellectual unification, what is the alternative means of eliciting consent ${ }^{79}$

With technology offering total surveillance and control, and the prospect of 'a new world money' (Wells 1940: 177), what is to counter a centrally dictated dependency on the one percent? Clearly there is a problem of trust ${ }^{80}$. As an economist puts it: 'The great diversity that marks our current world renders hyperglobalization incompatible with democracy' (Rodrik 2011: xix; and see Silver 2020; and Anonymous 2020). Have the descendants of the colonisers finally registered the import of Mathatha Tsedu's anti-

78 'In the debate over freedom versus control of the global network, China was largely correct, and the U.S. was wrong' (Goldsmith \& Woods 2020). See Jennifer Daskal \& Mia Sguang Li (2020); and Momoe Ban (2020). 'The independence of the writer and the artist is eaten away by vague economic forces, and at the same time it is undermined by those who should be its defenders' (Orwell 1962: 160).

79 'Non-resistance, the restriction of activities to moral suasion is no part of the programme of the Open Conspiracy. The forces of the entire movement may be mobilized in a variety of ways to bring pressure upon reactionary schools and institutions .... In the face of unscrupulous opposition creative ideas must become aggressive, must define their enemies and attack them ,,' (Wells 1933: 86). However, by 1940 Wells had concluded: 'It is not necessary to destroy existing governments as such. The idea of a federal world does not involve the creation of a common world government resembling the sovereign governments of the present time, pushing them aside and taking their place like a conqueror. It does not threaten in the least the racial and cultural distinctions of mankind' (Wells 2016: 99).

${ }^{80}$ In 1930 Olaf Stapledon described the situation after the Euro-American war: 'The planet was now a delicately organized economic unit, and big business in all lands was emphatically contemptuous of patriotism' (1999b: 43). After war between the America and China over diminishing fossil fuels the first World State emerged with improved living conditions but workers reduced to slaves under the tutelage of a fusion of religion and science. 
colonial and anti-apartheid parable about being reduced to a reserve army of colonised labour? Or is moral panic and 'the anxiety-provoking turmoil we are currently undergoing' (Derrida 2005: 157) displacing the process of analysis? If there is no alternative, is one left appealing to fairness in the face of the dispensers of progress: 'all as vain as the bleating of lost sheep' (Wells 1940a: 102)? ${ }^{81}$ The most we can say is that if you are not paranoid, you are not paying attention ${ }^{82}$.

In such a context, the worst possible outcome would be a state weakened, for example, by corruption and/or incompetence. International agencies would then be seen as means of disciplining the ruling party who would attempt to use that lever to assert their national hegemony. Working at one and the same time to shore up national sovereignty and abandon the nation state they will hope to save themselves by ascending to the safe haven of global governance. Leaving behind a weakened state, the national bourgeoisie would present themselves as defenders of the remains of national sovereignty and loyal intermediaries hammering out a necessary compromise with strategic intelligence (see World Economic Forum 2020). Is the colonialist trick - offer oneself as the solution to the problems one has created - to be repeated simultaneously at the national and the global level?

\section{Conclusion}

In Men like Gods, the liberal Barnstaple feels like 'a totally illiterate Gold

${ }^{81}$ For Kwame Nkrumah the alien was easy to identify but impossible to defeat: 'The evil of capitalism consists in its alienation of the fruit of labour from those who with the toil of their body and the sweat of their brow produce this fruit. This aspect of capitalism makes it irreconcilable with those basic principles which animate the traditional African society. Capitalism is unjust; in our newly independent countries it is not only too complicated to be workable, it is also alien' (Nkrumah 1970: 76).

${ }^{82}$ As Christian de Brie put it: 'Contemporary history can be described as that of the conquest of the world by an ever-smaller number of huge conglomerates organized into multinational corporations. These corporations are engaged in a permanent war with one another to control markets with the shared aim of subordinating all human endeavour to the logic of private profit' (1999: xi). 


\section{Shane Moran}

Coast negro trying to master thermos-electricity' (1923a: 338) and draws a lesson from the history of Utopia: confusion and conflict facilitate progress ${ }^{83}$. But who pays for transcending The Last Age of Confusion, this peace with-out victory? Wells's fiction suggests general human suffering: 'Yours are Age of Confusion Minds, trained to conflict, trained to insecurity and secret self-seeking' (252). Yet this 'view-point' (366) of transcendence, the leap into the future, with its calculus of necessary suffering, with its 'tanks and terraces' (369) ${ }^{84}$, is precisely what elicits the suspicion of an open, and not so open, conspiracy regarding the new world order. If 'It's time for a Great Reset of capitalism' (Schwab 2020), can it come about without increased dependency on the state (see Joubert 2020) $?^{85}$ And to whom shall the state be beholden?

When the main stream media time traveller of Men Like Gods returns to earth he muses on the time it will take for the recognisably human values exemplified on Utopia to be realised on earth. The blueprint for the transformation of human society involves unity, acculturation, centralisation under the wise gaze of an elite willing to bring about 'the high austere Utopian life that lies before us' (Wells 1923a: 286). Meanwhile, here amid

83 'The jewel on the reptile's head that had brought Utopia out of the confusions of human life, was curiosity, the play impulse, prolonged and expanded in adult life into an insatiable appetite for knowledge and an habitual creative urgency' (Wells 1923a: 342).

${ }^{84}$ Wells means water tanks as in 'great tanks of gleaming water' (1923a: 333) as seen from the 'parapet' (367) above, but the slippage from irrigation to fortification is revealing. Never forget that in the 'dynamics of globalization .... One must either be a global player or a loser' (Rothermund 2006: 274). 85 'Whatever governments do to solve a problem sooner or later produces another; that which ends one crisis makes the others worse; for every hydra head that is lopped off, two more grow in its place. Too many things have to be tackled at once; short-term fixes get in the way of long-term solutions; long-term solutions are not even attempted because short-term problems take priority; holes keep appearing that can be plugged only by making new holes elsewhere. Never since the Second World War have the governments of the capitalist West looked so clueless; never behind the façades of equanimity and tried political craftsmanship have there been so many indications of blind panic' (Streeck 2014: 10). 
'the tormented atmosphere of earth' (365) with psychological manipulation based on fear, Bolshevik and anti-Bolshevik conspiracies lurking in every shadow, newspapers peddle '[o]bvious lies about the Chinese' (375) and others. In the absence of collective and moral consciousness the murder of innocents continues, in the wake of Bloody Sunday Ireland's civil war festers, labour strikes rage and the great drought of 1921 augments the mood of financial despondency.

I imagine Barnstaple finding secreted in his pocket a report of current events from April 2020. (Utopians have a sense of humour too.) Headlines include increasing global power rivalry, deglobalisation and fragmentation, retreat to state sovereignty in response to public health dictates combined with the necessity of global coordination, predictions of increasing inequality, professions of faith in the recuperative potential of the free market and global financial system entangled with internal criticism of that system by its beneficiaries demanding an irrevocable break with the past. The unravelling of the new world order or its painful birth? Accusations of scaremongering and complacency fly.

In The Common Sense of War and Peace (1940), with regressive teleology confirmed by World War II, Wells reflects on his preoccupations from The Time Machine onwards. The sense of imminent catastrophe has only intensified: 'We are in the presence of one single world system which is breaking down' (Wells 2016: 24). He is careful to settle scores with those who have carica-tured him as an alarmist and censored him for advocating transformation over perpetual repetition. Invariably, he recalls, his adversaries have been wealthy and connected proponents of 'downward class hatred' (59). They use their influence over the media to stifle freedom of speech, often indirectly through well-meaning intermediaries: 'The real and dangerous discontent was from above' (37). It is, he warns, a situation that is unlikely to change when the media of enlightenment and education remain biased: 'You see what happened to the hopes of my generation and you see what may happen to yours' (123). Whether you interpret this prophesy as arising from the failure to create a new world order or as a consequence of trying to establish that world order (or perhaps both) will play a part in your interpretation of the present. 


\section{References $^{86}$}

Anonymous 2020. Financial Times. Are we Heading into Another Depression? Financial Times 3 June. Available at:

https://www.ft.com/content/f544bda2-a3fd-11ea-81ac-4854aed294e5 Arendt, H. [1982] 1992. Lectures on Kant's Political Philosophy. Beiner, R. (trans.). Chicago: University of Chicago Press.

Arendt, H. [1963] 2007. The Conquest of Space and the Stature of Man. The New Atlantis Fall: 43 - 55. Available at:

https://www.thenewatlantis.com/docLib/TNA18-Arendt.pdf

Arthur, P. 2010. Unfinished Projects: Decolonization and the Philosophy of Jean-Paul Sartre. London: Verso.

Ban, M. 2020. Pandemic to Usher in New World Order with China on Top: Dalio. Nikkei Asian Review 7 May. Available at:

https://asia.nikkei.com/Editor-s-Picks/Interview/Pandemic-to-usher-innew-world-order-with-China-on-top-Dalio

Barnard-Naudé, J. 217. Hannah Arendt's Work of Mourning: The Politics of Loss. 'The Rise of the Social' and the Ends of Apartheid. In van Bever Donker, M., R. Truscott, G. Minkley \& P. Lalu (eds): Remains of the Social: Desiring the Post-Apartheid. Johannesburg: Wits University Press.

Bell, D. 2018. Founding the World State: H.G. Wells on Empire and the English-Speaking Peoples. International Studies Quarterly 62, 4 December: 867 - 879. https://doi.org/10.1093/isq/sqy041

Bergonzi, B. 1961. The Early H.G. Wells: A Study of the Scientific Romances. Manchester: Manchester University Press.

https://doi.org/10.3138/9781442656864

Bogdanov, A. [1908] 1984. Red Star. Graham, L.H. \& R. Stites (eds.): Rougle, C. (trans.). Bloomington: Indiana University Press.

Bond, P. 2004. Facing Global Apartheid. In Freeman, A. \& B. Kagarlitsky (eds): The Politics of Empire: Globalisation and Crisis. London: Pluto

${ }^{86}$ In The World Brain (1938) Wells envisaged a complete planetary memory for all humanity that foreshadows the intellectual unification of the human race. He had in mind duplicable microfilm. Today Wells's own texts are part of that information bank, the Internet, without which this essay of 2020 would not have been written. Whether the technology is being used to unify or divide is an open question. 
Press. https://doi.org/10.2307/j.ctt18dzsfn.9

Bonn, M. 1934. The Age of Counter-Colonisation. International Affairs (Royal Institute of International Affairs 1931 - 1939) 13, 6, November -December: 845 - 847. https://doi.org/10.2307/2603330

Borowy, I. 2009. Coming to Terms with World Health: The League of

Nations Health Organisation 1921 - 1946. Oxford: Peter Lang.

https://doi.org/10.3726/978-3-653-05143-8

Bradbury, R. [1950] 1979. - And the moon be still as bright. In The Martian

Chronicles. New York: Doubleday \& Company.

Brown, F. 1954. Sentry. In Two Timer. Available at:

http://www.gutenberg.org/files/29948/29948-h/29948-h.htm

Brown, W. 2009. Sovereign Hesitations. In Cheah, P. \& S. Guerlac (eds):

Derrida and the Time of the Political. London: Duke University Press.

Burgers, J.H. 1992. The Road to San Francisco: The Revival of the Human

Rights Idea in the Twentieth Century. Human Rights Quarterly 14, 4,

November: 447 - 477. Available at:

http://humanrightsinitiative.ucdavis.edu/files/2012/10/burgerroadtosf.p df; https://doi.org/10.2307/762313

Byrne, D. 2004/5. Science Fiction in South Africa. Proceedings of the Modern Language Association of America 119, 3, January: 522 - 525. https://doi.org/10.1632/003081204X20596

Campbell, P. Crawford 1923. Chinese Coolie Emigration to Countries within the British Empire. London: P.S. King \& Son, Ltd. Available at: https://archive.org/details/in.ernet.dli.2015.90706

Caudwell, C. 1938. Studies in a Dying Culture. London: John Lane The Bodley Head. Available at:

https://ia801306.us.archive.org/10/items/in.ernet.dli.2015.182674/201

5.182674. Studies-In-A-Dying-Culture.pdf

Chesterton, G.K. [1909] 2000. The Red Angel. In Manguel, A. (ed): On

Lying in Bed and Other Essays. Canada: Bayeaux Arts, E-Book.

Chesterton, G.K. 2014. The G.K. Chesterton Collection. 50 Books. Catholic Publishing Inc.: E-Book.

Cixin, L. [2008] 2016. The Dark Forest. Martinsen, J. (trans.). London: Head of Zeus Ltd.

Clarke, A. C. [1953] 1990. Childhood's End. New York: Del Ray.

Clarke, I. F. [1966] 1992. Voices Prophesying War: Future Wars, 1763 1984. Oxford: Oxford University Press. 
Cole, S. 2020. Inventing Tomorrow: H.G. Wells and the Twentieth Century. New York: Columbia University Press.

https://doi.org/10.7312/cole19312

Communist Party of South Africa 1921. Manifesto of the Communist Party of South Africa. Cape Town, 30 July. Available at:

https://www.marxists.org/history/international/comintern/sections/sacp /1921/manifesto.htm

Condorcet [1795] 2012. The Sketch. In Lukes, S. \& N. Urbinati (eds.): Condorcet: Political Writings. Cambridge: Cambridge University Press.

Conrad, J. [1902] 1988. Heart of Darkness. Kimbrough, R. (ed.). New York: W.W. Norton \& Company.

Daskal, J. \& M. Sguang Li 2020. Lessons from China on the Coronavirus and the Dangers of App Consolidation. Slate 16 March. Available at: https://slate.com/technology/2020/03/china-coronavirus-tencentwechat-facebook-consolidation-censorship.html

de Brie, C. [1998] 1999. Foreword. In Toussaint, E.: Your Money or Your Life: The Tyranny of Global Finance. Krishnan, R. and V. Briault Manus (trans.). London: Pluto Press.

Deloitte 2018. The Future of Mining in Africa: Navigating a Revolution. Available at:

https://www2.deloitte.com/content/dam/Deloitte/za/Documents/energy -resources/za_Future_of_mining.pdf

Derrida, J. [2003] 2005. Rogues: Two Essays on Reason. Brault, PascaleAnne \& Michael Naas (trans.). Stanford: Stanford University Press.

Diment, G. 2019. H.G. Wells and All Things Russian. EPUB: Anthem Press. https://doi.org/10.2307/j.ctvkwnmn2

Dubow, S. 2008. Smuts, the United Nations and the Rhetoric of Race and

Rights. Journal of Contemporary History 43, 1: 43 - 72. Available at: http://www.sahistory.org.za/sites/default/files/03\%20Dubow-

\%20Smuts\%20and\%20the\%20UN.pdf

Freeman, A. \& B. Kagarlitsky 2004. Introduction: World Empire - or a World of Empires. In Freeman, A. \& B. Kagarlitsky (eds): The Politics of Empire: Globalisation and Crisis. London: Pluto Press.

https://doi.org/10.2307/j.ctt18dzsfn.3

Gates, B. 2010. Innovating to Zero. TED2010. Youtube. Available at: https://www.youtube.com/watch?v=JaF-fq2Zn7I 
Georgieva, K. 2020. The Great Reset: Remarks to World Economic Forum. International Monetary Fund 22 May. Available at:

https://www.imf.org/en/News/Articles/2020/06/03/sp060320-remarksto-world-economic-forum-the-great-reset

Goldberg, J. [2007] 2009. Liberal Fascism; The Secret History of the American Left, from Mussolini to the Politics of Change. New York: Random House, Inc.

Goldsmith, J. \& A. Keane Woods 2020. Internet Speech Will Never Go Back to Normal. The Atlantic 25 April. Available at:

https://www.theatlantic.com/ideas/archive/2020/04/what-covidrevealed-about-internet/610549/

Goode, L. \& A. Rogers 2020. Global Warming. Inequality. Covid-19. And Al Gore Is ... Optimistic? Wired 8 July. Available at:

https://www.wired.com/story/global-warming-inequality-covid-19and-al-gore-is-optimisticl

Gravett, W.H. 2015. 'To Save Succeeding Generations from the Scourge of War': Jan Christian Smuts (1870 - 1950) and the Genesis of International Organisation and Human Rights. Doctoral Thesis. University of Pretoria. Available at: https://repository.up.ac.za/bitstream/handle/2263/52402/Gravett_Save 2015.pdf; sequence $=1$

Haggard, H.R. 1980. The Private Diaries of Sir H. Rider Haggard, 1914 1925. Higgins, D.S. (ed). New York: Stein \& Day.

Hankins, G. 2019. Interwar Modernism and the Liberal World Order: Offices, Institutions, and Aesthetics After 1919. Cambridge: Cambridge University Press.

https://doi.org/10.1017/9781108626323

Harrison, F.V. 2008. Global Apartheid, Foreign Policy, and Human Rights. In Manning, M. \& Vanessa Agard-Jones (eds): Transnational Blackness: Navigating the Global Color Line. New York: Palgrave Macmillan.

https://doi.org/10.1057/9780230615397 3

Hobson, J.A. 1900. The War in South Africa: Its Causes and Effects. London: James Nisbet \& Co. Available at:

https://archive.org/details/warinsouthafrica00hobsuoft

Husserl, E. 2001 [1901/2] Logical Investigations, Volume 1. Findlay, J.N. (trans.). New York: Routledge. 


\section{Shane Moran}

Hyde, W.J. 1956. The Socialism of H.G. Wells in the Early Twentieth Century. Journal of the History of Ideas 17, 2, April: 217 - 234. https://doi.org/10.2307/2707743

Icke, D. 2004. David Icke \& Credo Mutwa - The Reptilian Agenda (Part 1). Youtube. Available at:

https://www.youtube.com/watch?v=4apWOUNOx64

Jameson, F. 2005 [2003] Fear and Loathing in Globalization. In Archaeologies of the Future: The Desire Called Utopia and other Science Fictions. London: Verso.

Joubert, C. 2020. The Great Reset. Goldbroker 17 June. Available at:

https://www.goldbroker.com/news/the-great-reset-

1878\#: : text=The\%20Great $\% 20$ RESET $\% 20$ On\%20June $\% 203 \% 2 \mathrm{C} \%$

$202020 \% 20 \% 2 \mathrm{C}$,she\%20declared\%20that\%20this\%20epidemic\%20is $\% 20$ an $\% 20$

Kant, I. [1784] 1991. [Idea for a Universal History with a Cosmopolitan Purpose. In Reiss, H. (ed.): Political Writings. Nisbet, H.B. (trans.). Cambridge: Cambridge University Press. https://doi.org/10.1017/CBO9780511809620.004

Kant, I. [1788] 1996. Critique of Practical Reason. In Gregor, Mary J. (ed. \& trans.): Practical Philosophy. Cambridge: Cambridge University Press, 1996, 133-271.

Critique of Practical Reason. Pluhar, W. (trans.). Cambridge: Hackett Publishing Company.

Keegan, T. 1990. Primitive Accumulation and Class Formation in the Making of Agrarian Capitalism in South Africa. Collected Seminar Papers. Institute of Commonwealth Studies 40: 198 - 211. Available at: Tim_Keegan_-

Primitive accumulation and class formation in the making of ag rarian_capitalism_in_South_Africa.pdf (sas.ac.uk)

Koehler, G. 1995. The Three Meanings of Global Apartheid: Empirical, Normative, Existential. Alternatives: Global. Local, Political 20, 3, July - September: 403 - 413. https://doi.org/10.1177/030437549502000305 Lauren, P. G. [2003] 2011. The Evolution of International Human Rights:

Visions Seen. Philadelphia: University of Pennsylvania Press. https://doi.org/10.9783/9780812209914

Lehohla, P. 2018. Opinion: Digital Colonialism on the African Continent. Business Report 16 October. Available at: 
https://www.iol.co.za/business-report/opinion/opinion-digitalcolonialism-on-the-african-continent-17493010

Lenin, V.I. 1968. Collected Works, Volume 39, Notes on Imperialism. Moscow: Progress Publishers.

Lenin, V.I. 1964. Data on Development of Capitalism in Agriculture. In Collected Works, December 1915 - July 1916. London: Lawrence \& Wishart/ Progress Publishers.

Losurdo, D. [2002] 2019. Nietzsche, the Aristocratic Rebel: Intellectual Biography and Critical Balance-Sheet. Benton, G. (trans.). Leiden: Brill. https://doi.org/10.1163/9789004270954

Magubane, B. 1986. South Africa: On the Verge of Revolution. Ufahamu: A

Journal of African Studies 15, 1-2: 22 - 57. Available at:

https://repositories.cdlib.org/uc/item/2d3649kd

Magubane, B. 1996. The Making of a Racist State: British Imperialism and the Union of South Africa, 1875 - 1910. Trenton, NJ: Africa World Press Inc. https://doi.org/10.5070/F7151-2016992

Marcosson, I.F. 1921. An African Adventure. New York: John Lane Company. https://doi.org/10.5479/sil.794054.39088018042796

Marks, S. \& S. Trapido 1979. Lord Milner and the South African State. History Workshop 8, Autumn: 50 - 80.

https://doi.org/10.1093/hwj/8.1.50

Marlowe, J. 1976. Milner: Apostle of Empire. A Life of Alfred George the Right Honourable Viscount Milner of Dt James's and Cape Town, KG, GCB, GCMG (1854 - 1925). London: Hamish Hamilton.

McKay, C. [1937] 1970. A Long Way from Home. New York: Harvest.

Mercier, L-S. [1771] 1772. Memoirs of the Year Two Thousand Five Hundred, Volume II. Hooper, W. (trans.). London. Available at:

https://archive.org/details/memoirsofyeartwo02merc

Milanovic, B. 2019. Capitalism Alone: The Future of the System that Rules the World. London: Harvard University Press.

https://doi.org/10.4159/9780674242852

Milner, A. 1913. The Nation and Empire: Being a Collection of Speeches and Addresses. London: Constable \& Company. Available at: https://archive.org/details/nationempirebein00miln/page/n8/mode/2up

Morris, M. 1976. The Development of Capitalism in South African Agriculture: Class Struggle in the Countryside. Economy and Society 5, 5: 292 - 243. https://doi.org/10.1080/03085147600000014 
Morris, M. 1987. Social History and the Transition to Capitalism in the South African Countryside. African Perspective 5 - 6: 7 - 24.

Morton, O. 2015. The Planet Remade: How Geoengineering Could Change the World. Princeton, NJ: Princeton University Press.

https://doi.org/10.1515/9781400874453

Mullings, L. 2008. Race and Globalization: Racialization from Below. In Marable, M. \& V. Agard-Jones (eds): Transnational Blackness: Navigating the Global Color Line. New York: Palgrave Macmillan. https://doi.org/10.1057/9780230615397_2

Nelson, R.F. [1963] 2014. Eight O'Clock in the Morning. In Clarke, A.C. \& K.K. Rusch (eds): The Ninth Science Fiction Megapack. Maryland: Wildside Press LLC, E-book.

Olivier, S. 1918. The League of Nations and Primitive Peoples. London: Oxford University Press. Available at:

https://archive.org/details/leagueofnationsp00oliv/page/1

Orwell, G. [1941] 1951. Wells, Hitler and the World State. In Critical Essays. London: Secker \& Warburg.

Orwell, G. [1946] 1962. The Prevention of Literature. In Inside the Whale and Other Essays. Middlesex: Penguin Books.

Parrinder, P. 1976. News from Nowhere, the Time Machine. and the BreakUp of Classical Realism. Science-Fiction Studies 3: 65 - 274.

Parry, B. 2004. Postcolonial Studies: A Materialist Critique. London: Routledge.

Parsons, R.W.K. 1983. Keynes and South Africa. South African Journal of Economics 51, 3, September: $280-290$.

https://doi.org/10.1111/j.1813-6982.1983.tb00802.x

Pasolini, PP. [1976] 1987. Lutheran Letters. Hood, S. (trans.). New York: Carcanet.

Pilger, J. 2002. John Pilger Reveals the American Plan: A New Pearl Harbour. 16 December. https://www.newstatesman.com/node/192545

Potter, R. 1982. The Germ Growers. An Australian Story of Adventure and Mysteries. London: Hutchinson \& Co. Available at:

https://www.gutenberg.org/files/60312/60312-h/60312-h.htm

Pound, E., [\#5, 7 December 1941] 1978. Those Parentheses. In Doob, L.W.

(ed.): Ezra Pound Speaking: Radio Speeches of World War II. London:

Greenwood Press.

Project for the New American Century 2000. Rebuilding America's Defen- 
ces: Strategy, Forces and Resources for a New Century. September. Available at:

https://ia803100.us.archive.org/32/items/RebuildingAmericasDefenses /RebuildingAmericasDefenses.pdf

Rice Burroughs, E. 1917. A Princess of Mars. Available at:

https://www.gutenberg.org/files/62/62-h/62-h.htm

Rice Burroughs, E. [1923] 1981. The Moon Maid. USA: Ace. Available at: http://www.gutenberg.net.au/ebooks06/0601501h.html

Rieder, J. 2008. Colonialism and the Emergence of Science Fiction. Connecticut: Wesleyan University Press.

Rieder, J. 2009. Spectacle, Technology and Colonialism in SF Cinema: The Case of Wim Wenders' Until the End of the World. In Bould, M. \& C. Miéville (eds.): Red Planets: Marxism and Science Fiction. Middletown, Connecticut: Wesleyan University.

Rodrik, D. 2011. The Globalization Paradox: Why Global Markets, States, and Democracy Can't Coexist. Oxford: Oxford University Press.

Rönnbäck, K. \& O. Broberg 2019. Capitalism and Colonialism: The Return on British Investments in Africa 1869 - 1969. London: Palgrave Macmillan. https://doi.org/10.1007/978-3-030-19711-7

PMCid:PMC6549124

Rothermund, D. 2006. The Routledge Companion to Decolonization. London: Routledge.

https://doi.org/10.4324/9780203002643

Schumpeter, Joseph A. [1942] 2003. Capitalism, Socialism and Demcracy.

London: Routledge.

Schwab, K. 2016. The Fourth Industrial Revolution. World Economic Forum. Available at:

https://www.weforum.org/agenda/2016/01/the-fourth-industrialrevolution-what-it-means-and-how-to-respond/

Schwab, K. 2020. It's time for a Great Reset of Capitalism. Mail \& Guardian 3 June. Available at:

https://mg.co.za/coronavirus-essentials/2020-06-03-its-time-for-agreat-reset-of-capitalism/

Semmel, B. 1960. Imperialism and Social Reform: English Social-Imperial Thought, 1895 - 1914. London: George Allen \& Unwin.

Silver, C. 2020. El-Erian on the Long-Term Effects of the Crisis. Investopedia 30 April. Available at: 
https://www.investopedia.com/mohamed-el-erian-on-the-impact-ofthe-global-pandemic-on-economies-and-markets-4843795

Skouras, S. 2020. David Icke Interview: Bill Gates, Elon Musk \& Soros are Frontmen for the Top of the Pyramid. YouTube. 17 April. Available at: https://www.youtube.com/watch?v=F3zKaZlKaDY

(This video os no longer available because the YouTube account associated with this video has been terminated.)

Slobodian, Q. 2018. Globalists: The End of Empire and the Birth of Neoliberalism. London: Harvard University Press.

https://doi.org/10.4159/9780674919808

Smith, E.D. 2012. Globalization, Utopia, and Postcolonial Science Fiction. London: Palgrave Macmillan. https://doi.org/10.1057/9781137283573

Somos, M. 2011. 'A Century of Hate and Coarse Thinking': AntiMachiavellian Machiavellianism in H.G. Wells. The New Machiavelli.

History of European Ideas 37, 2: 137 - 152.

https://doi.org/10.1016/j.histeuroideas.2011.01.008

Stalin, JV. [1934] 1978. Marxism Versus Liberalism. An Interview with H.G. Wells. Works, Volume 14. 1934-1940. England: Red Star Press Ltd. Available at:

https://www.marxists.org/reference/archive/stalin/works/1934/07/23.ht $\underline{\mathrm{m}}$

Stapledon, O. [1937] 1999a. Star Maker. London: Millennium. Available at: http://gutenberg.net.au/ebooks06/0601841h.html

Stapledon, O. [1930] 1999b. Last and First Men: A Story of the Near and Far Future. London: Millennium. Available at:

https://upload.wikimedia.org/wikipedia/commons/5/5c/Last and First Men.pdf

Streeck, W. [2013] 2014. Buying Time: The Delayed Crisis of Democratic Capitalism. Camiller, P. (trans.). London: Verso.

Suvin, D. 1979. Metamorphoses of Science Fiction: On the Poetics and History of a Literary Genre. New Haven: Yale University Press.

Thucydides 1954. The Peloponnesian War. Warner, R. (trans). London: Penguin Books.

Tolstoi, A. [1923] 1950. Aelita. Flaxman, L. (trans.). Moscow: Foreign Language Publishing House.

Toye, R. 2008. H.G. Wells and the New Liberalism. Twentieth Century British History 19, 2: 156 - 185. Available at: 
https://ore.exeter.ac.uk/repository/handle/10871/9426;

https://doi.org/10.1093/tcbh/hwn007

Trilling, L. [1943] 1965. E.M. Forster. New York: New Directions.

Tsedu, M. 1980. Forced Landing. In Mutloatse, M. (ed): Forced Landing. Africa South: Contemporary Writings. Johannesburg: Ravan Press.

United Nations 2017. Secretary-General's Remarks at the World Government Summit with Q\&A. Office of the Secretary-General's Envoy on Youth. Available at:

https://www.un.org/youthenvoy/2017/02/secretary-generals-remarksworld-government-summit-qa/

van der Poel, J. (ed.) 1973a. Selections from the Smuts Papers: Volume 5, September 1919 - November 1934. Cambridge: Cambridge University Press.

van der Poel, J. (ed.) 1973b. Selections from the Smuts Papers: Volume 6, December 1934 - August 1945. Cambridge: Cambridge University Press.

Visser, N. 1993. The Politics of Future Projection in South African Fiction.

In Fletcher, P. (ed.): Black/White Writing: Essays on South African Literature. Lewisburg: Bucknell University Press.

Wagar, W.W. 1961. H.G. Wells and the World State. New Haven: Yate University Press.

Wallerstein, I. (with Joan Smith) [1992] 2000. Households as an Institution of the World-Economy. In The Essential Wallerstein. New York: The New Press, 234-252.

Weaver, R. 2010. 'Smudged, Distorted and Hidden': Apocalypse as Protest in Indigenous Speculative Science Fiction. In Hoagland, E. \& R. Sarwal (eds.): Science Fiction, Imperialism and the Third World: Essays on Postcolonial Literature and Film. London: McFarland \& Company, Inc. Webster, N.H. 1924. Secret Societies and Subversive Movements. London: Boswell Printing \& Publishing Co., Ltd. Available at: https://archive.org/details/SecretSocietiesAndSubversiveMovementsN estaHelenWebster

Wells, H.G. [1898] 1894. Aepyornis Island. In Thirty Strange Stories. New York \& London: Harper \& Brothers Publishers. Available at: http://www.gutenberg.org/files/59774/59774-h/59774-h.htm

Wells, H.G. 1896. The Wheels of Chance. A Bicycling Idyll. Available at: http://www.gutenberg.org/files/1264/1264-h/1264-h.htm 
Wells, H.G. 1897. Certain Personal Matters. London: T. Fisher Unwin. Available at:

https://archive.org/details/certainpersonal02wellgoog/page/n11/mode/ 2up

Wells, H.G. [1901] n.d. The First Men in the Moon. In The First Men in the Moon, The World Set Free, \& Short Stories. London: Odhams Press Ltd. Wells, H.G. [1901] 1902. Anticipations of the Reaction of Mechanical and Scientific Progress Upon Human Life and Thought. $4^{\text {th }}$ Edition. London: Chapman \& Hall, Available at:

https://ia800302.us.archive.org/32/items/anticipationsofr00welluoft/an ticipationsofr00welluoft.pdf

Wells, H.G. [1903] 1904. Mankind in the Making. London: Chapman \& Hall, $4^{\text {th }}$ Edition. Available at:

https://archive.org/details/mankindinmaking00welluoft

Wells, H.G. [1894] 1904a. The Lord of the Dynamo. In The Stolen Bacilli and Other Stories. London: Methuen \& Co., 192-213.

Wells, H.G. 1905. A Modern Utopia. London: Thomas Nelson \& Sons. Available at: https://archive.org/details/modernutopia00welluoft

Wells, H.G. 1908a. This Misery of Boots. Boston: The Ball Publishing Co. Available at: https://archive.org/details/thismiseryofboot00well

Wells, H.G. 1908b. The War in the Air, and Particularly How Mr. Bert Smallways Fared While it Lasted. London: George Bell \& Sons. https://doi.org/10.5479/sil.549464.39088008979957

Wells, H.G. [1910] n.d. The New Machiavelli \& The Food of the Gods. London: Odhams Press.

Wells, H.G. 1913. The Passionate Friends. USA: Harper \& Brothers. Available at: http://www.gutenberg.org/files/30340/30340-h/30340$\underline{\text { h.htm }}$

Wells, H.G. 1914. An Englishman Looks at the World: Being a Series of Unrestrained Remarks upon Contemporary Matters. London: Cassell \& Company, Ltd.

Wells, H.G. 1915. The Wife of Sir Isaac Harman. New York: The Macmillan Company.

Wells, H.G. 1916. What is Coming: A European Forecast. New York: The Macmillan Company.

Wells, H.G. 1917. The Soul of a Bishop. New York: The Macmillan Company. 
Wells, H.G. 1918a. In the Fourth Year: Anticipations of a World Peace. London: Chatto \& Windus. Available at:

http://www.gutenberg.org/cache/epub/10291/pg10291.html

Wells, H.G. [1918b] n.d. Joan and Peter. The Story of an Education. In Joan and Peter \& The Country of the Blind. London: Odhams Press Limited.

Wells, H.G. 1919. The Idea of a League of Nations. The Atlantic January. Available at:

https://www.theatlantic.com/magazine/archive/1919/01/the-idea-of-aleague-of-nations/306270/

Wells, H.G. 1920. The Outline of History, Being a Plain History of Life and Mankind. New York: The Macmillan Company. Available at: https://archive.org/details/OutlineOfHistory

Wells, H.G. [1921a, 1899] n.d. The Sleeper Awakes. In The Sleeper Awakes \& Men Like Gods. London: Odhams Press Limited.

Wells, H.G. 1921b. Russia in the Shadows. New York: George H. Doran Company. Available at: https://archive.org/details/russiainshadows00wellgoog

Wells, H.G. 1922. Washington and the Riddle of Peace. New York: The Macmillan Company. Available at:

https://archive.org/details/washingtonandri01wellgoog

Wells, H.G. 1923a. Men Like Gods. In The Sleeper Awakes \& Men Like Gods. London: Odhams Press Limited.

Wells, H.G. 1923b. Mr. Blettsworthy on Rampole Island. London: Ernest Benn Limited.

Wells, H.G. 1927. Meanwhile (The Picture of a Lady). New York: George H. Doran Company.

Wells, H.G. 1930. The Autocracy of Mr. Parham: His Remarkable Adventures in the Changing World. London: William Heinemann Ltd.

Wells, H.G. 1932. The Work, Wealth and Happiness of Mankind. London: Heinemann.

Wells, H.G. [1928] 1933. The Open Conspiracy: What are We to Do with Our Lives? Dumfries \& Galloway: Anodos Books.

Wells, H.G. 1935 [1933] The Shape of Things to Come. The Ultimate Revolution. London: Hutchinson \& Co.

Wells, H.G. 1937. Star-Begotten. A Biological Fantasia. New York: The Viking Press. Available at:

https://archive.org/details/WellsH.G.StarBegotten 1937 
Wells, H.G. 1938. The World Brain. London: Methuen \& Co. Available at: http://gutenberg.net.au/ebooks13/1303731h.html

Wells, H.G. 1939a. The Fate of Man. New York: Alliance Book Corporation, Longman Green \& Co.

https://archive.org/details/fateofman013812mbp

Wells, H.G. 1939b. The Holy Terror. London: Michael Joseph. Also available at:

http://gutenberg.net.au/ebooks06/0608211h.html

Wells, H.G. 1940a. The New World Order. Whether it is Attainable, How it Can be Attained, and What Sort of World a World at Peace will have to be. London: Secker \& Warburg. Available at:

https://archive.org/details/TheNewWorldOrder

Wells, H.G. 1940b. All Aboard for Ararat. London: Secker \& Warburg. Available at:

https://ia802904.us.archive.org/13/items/in.ernet.dli.2015.158780/201

5.158780.All-Aboard-For-Ararat.pdf

Wells, H.G. 1941. Guide to the New World: A Handbook of Constructive World Revolution. London: Victor Gollancz Ltd.

WellsGuide.pdf

Wells, H.G. 1964. Winston Churchill. In Wagar, W. Warren (ed.): H.G. Wells: Journalism and Prophecy 1893 - 1946. Cambridge: The Riverside Press. Available at:

https://archive.org/details/journalismprophe00well/mode/2up

Wells, H.G. [1934] 1967. Experiment in Autobiography: Discoveries and Conclusions of a Very Ordinary Brain (Since 1866). New York: JB

Lippincott. Available at: http://gutenberg.ca/ebooks/wellshgautobiography/wellshg-autobiography-00-h-dir/wellshgautobiography-00-h.html

Wells, H.G. [1926] 1972. The World of William Clissold. A Novel at a New Angle. Volume 1. Westport, Connecticut: Greenwood Press.

Wells, H.G. [1895] 1995. The Time Machine. New Delhi: UBS Publishers.

Wells, H.G. [1898] 2012. The War of the Worlds. UK: Penguin Books.

Wells, H.G. [1940] 2016. The Common Sense of War and Peace: World Revolution or War Unending. Read Books Ltd.

Wells, H.G. n.d. Machin Nan Tan. UK: Lightening Source.

Woolf, Leonard 1920. Economic Imperialism. London: The Swarthmore Press Ltd. 
World Economic Forum 2020. Strategic Insights and Contextual Intelligence from the World Economic Forum. 17 September. Available at: https://intelligence.weforum.org/

Žižek, S. 1999. Carl Schmitt in the Age of Post-Politics. In Mouffe, C. (ed): The Challenge of Carl Schmitt. London: Verso.

Žižek, S. 2009 Through the Glasses Darkly. Socialist Review 341, November. Available at:

http://socialistreview.org.uk/341/through-glasses-darkly

Žižek, S. 2014 Slavoj Žižek webchat - as it happened. 8 October. Available at: https://www.theguardian.com/books/live/2014/oct/06/slavoj-zizekwebchat-absolute-recoil

Žižek, S. 2015 Slavoj Žižek, on Looming Split between Capitalism and Democracy and Rise of Neo-Apartheid. The South African Civil Society Information Service 22 January. http://sacsis.org.za/site/article/2255.

Žižek, S. 2020. Pandemic! COVID-19 Shakes the World. New York: OR Books. https://doi.org/10.2307/j.ctv16t6n4q

Zwiggelaar, G. 212. Journey to the Underside. USA: America Star Books.

Shane Moran

English Studies

University of Fort Hare

South Africa

SMoran@ufh.ac.za 